John Carroll University

Carroll Collected

2020

The influence of firm performance and (level of) assurance on the believability of management's environmental report

Mark D. Sheldon

J. Gregory Jenkins

Follow this and additional works at: https://collected.jcu.edu/fac_bib_2020

Part of the Accounting Commons 


\title{
The influence of firm performance and (level of) assurance on the believability of management's environmental report
}

\begin{abstract}
Purpose - This study empirically examines perceptions of environmental report believability based on a firm's relative performance and level of assurance obtained on environmental activities under the recently clarified and recodified attestation standards in the United States.

Design/methodology/approach - The paper uses a $2 \times 3$ between-subjects experiment to identify differences in 153 non-expert environmental report users' perceptions of report believability based on positive or negative firm performance and (level of) assurance provided by an accounting firm.

Findings - Results show a main effect in that negative performance reports are perceived to be more believable than positive performance reports, as driven by negative performance reports being significantly more believable when no assurance is present. The firm performance effect is eliminated once limited or reasonable assurance is provided. Further, positive performance reports with limited, but not reasonable, assurance are perceived to be more believable than reports without assurance. No differences are identified within the negative performance condition.

Practical implications - Limited assurance might be used as an impression management tool to enhance the believability of positive performance environmental reports. Users, practitioners, and standard-setters should also be aware that users might believe environmental reports are assured, even when no such assurance has been provided.

Originality/value - This paper examines the impact of assured environmental reporting on users that review firms' environmental reports outside of a shareholder/investor role. The study also demonstrates conditions in which firm performance and assurance impact perceptions of report believability.
\end{abstract}

Keywords Environmental CSR reports, Attestation, Reasonable assurance, Limited assurance

Paper type Research paper

\section{Introduction}

Corporate social responsibility (CSR) reporting is largely a voluntary activity in the United States (US) (GRI, 2014a), and firms that make these disclosures tend to focus on areas of positive performance (Deegan and Gordon, 1996; Deegan and Rankin, 1996; Cho and Patten,

This study is based on the first author's dissertation. Both authors wish to thank the dissertation committee for their time and valuable input: Bowe Hanson, Velina Popova, Sarah Stein, and Kevin Carlson. We also appreciate the helpful comments of Charles Boster, Matt Hayes, Porschia Nkansa, Josette Pelzer, Andrea Sheetz, Ian Twardus, Joe Ugras, Ally Zimmerman, and workshop participants at American University, John Carroll University, and Virginia Tech. We also thank participants at the American Accounting Association's 2018 Annual Meeting for their helpful comments. Mark is also grateful for financial support provided by Virginia Tech's Pamplin College of Business and the AICPA Foundation's Accounting Doctoral Scholarship (ADS). We also appreciate the helpful suggestions from two anonymous reviewers. 
2007; Holder-Webb et al., 2009; Boiral, 2013; Cho et al., 2015a)[1]. At the same time, a growing number of companies now obtain assurance on their CSR reports (KPMG, 2017). This environment introduces an interesting question to management, whether or not to have their CSR report assured. Theory on firm performance suggests that reports of positive firm performance are less inherently believable, and thus might be more believable if independently assured (Williams, 1996; Hutton et al., 2003; Mercer, 2004). However, if a firm consumes resources to voluntarily track and report CSR activities, must it also then purchase (a certain level of) assurance on positive performance results so that these are perceived to be as believable as if the firm had reported negative results? This study uses an experiment to examine perceptions of environmental CSR report believability for firms that disclose positive or negative performance and obtain no, limited, or reasonable assurance from an accounting firm under the recently clarified and recodified attestation standards in the US (AICPA, 2016). In doing so, the paper studies non-expert environmental report users who are not evaluating the report as part of an investment or firm-valuation decision. The study therefore responds to a call by Moser and Martin (2012) to examine the impact of accountability reporting on users that confront this information outside of a wealthmaximization decision, and thus acknowledges that such "disclosures could serve a broader purpose than simply providing value-relevant information to shareholders" (p. 798).

Environmental reporting is a subset of CSR reporting, which is an organization's disclosure of the "economic, environmental and social impacts caused by its everyday activities" (GRI, 2014a). While accounting firms, specialty consultants, and others provide assurance on CSR disclosures (O'Dwyer and Owen, 2005; Simnett et al., 2009; Peters and Romi, 2014), this study focuses on independent assurance from accounting firms given the widespread efforts of the profession to offer a robust CSR assurance framework (Peters and Romi, 2014; AICPA, 2017). Several accounting studies show that assurance from accountants influences users' perceptions of financial and non-financial information (e.g. Kinney, 2000; Mercer, 2004; Simnett et al., 2009; Pflugrath et al., 2011). However, it is not yet clear whether users differentiate between levels of assurance (Hasan et al., 2003; Schelluch and Gay, 2006; Hodge et al., 2009; Low and Boo, 2012; Rivière-Giordano et al., 2018). The clarified and recodified US attestation standards (herein, the "clarified US attestation standards") allow independent accountants to provide limited or reasonable assurance on CSR disclosures for review or examination engagements, respectively (AICPA, 2016). Of the US firms that issued assured CSR reports in accordance with the Global Reporting Initiative's (GRI) framework in 2013, a total of 76.2 percent (32/42) were issued with limited assurance and the balance with reasonable assurance (GRI, 2014b).

This paper finds evidence that non-expert environmental report users expect companies will disclose favorable performance reports. As such, the study is consistent with Verrecchia's (1983) discussion that, with discretionary disclosures, users have rational expectations that management will withhold unfavorable news. Psychology theory on communication suggests that individuals are more influenced by a message when their expectation of that message is disconfirmed (Eagly et al., 1978). This suggests that management's report depicting negative environmental performance should be perceived as more believable than when reporting positive performance. Because information about a firm's negative environmental performance should be perceived as more believable, there may be less opportunity for external assurance to incrementally enhance report believability, making it less likely that users will differentiate between no assurance and the different levels of assurance for firms with negative performance. Along the same lines, users may find positive performance disclosures to be less inherently believable (Mercer, 2004). Thus, there should be more of an opportunity for assurance to enhance the perceived believability of management's report for companies with positive performance (cf. Kinney, 2000), such that users will differentiate between no assurance and the different levels of assurance. 
This study uses a $2 \times 3$ experimental design in which relative firm environmental performance (positive or negative) and assurance provided (none, limited, or reasonable assurance) are manipulated between participants. Participants were 153 individuals residing in the US, with general business knowledge and experience with investing activities as recruited through a crowdsourcing service, Amazon Mechanical Turk. This study refers to the participants as non-expert environmental report users because they should have an understanding of firm disclosures, but need not be experts with environmental-specific disclosures. Further, participants were not primed to approach their role from an investment or firm valuation perspective, and thus their responses should be representative of a broad group of stakeholders. The experiment focused on one aspect of environmental reporting, greenhouse gas emissions, and was administered using Qualtrics. Each participant reviewed the environmental report for a hypothetical company that indicated either positive or negative performance relative to the industry average across a series of indicators. Then, participants in an assurance condition read the associated independent accountant's report that presented either a limited or a reasonable level of assurance. After reading the experimental materials, participants were asked a series of questions to capture the dependent variables, three of which were used to create an index to assess perceptions of the believability of management's environmental report.

The focus of this study on believability comes from (1) Kinney's (2000) finding that independent assurance enhances the credibility of management's disclosures, and (2) Mercer's (2004) clarification that disclosure credibility represents "perceptions of the believability of a particular disclosure" (p. 186). Therefore, this paper interprets previous studies on disclosure/report credibility as pursuits to determine if users found the associated information to be believable. To perform a comprehensive review of disclosure/report credibility, it is necessary to acknowledge that the extant literature largely uses the terms credibility and reliability in much the same way (e.g. Flanagin and Metzger, 2000; Kinney, 2000; Fargher and Gramling, 2003; Mercer, 2004; Schelluch and Gay, 2006; Nugent and Simnett, 2007; Hodge et al., 2009; Simnett et al., 2009; Pflugrath et al., 2011). As such, this study considers previous findings about perceptions of disclosure/report credibility and/or reliability to develop a theoretical argument for what makes disclosures/reports more (or less) believable to users.

Findings indicate that users perceive environmental reports to be believable, but there is no main effect for the provision/level of assurance obtained. Consistent with the theory (e.g. Williams, 1996; Hutton et al., 2003; Mercer, 2004), there is a main effect for firm performance in which negative performance reports are perceived to be more believable than positive performance reports. Further analyses reveal this effect is driven by negative performance reports being perceived as significantly more believable when no assurance is present. The firm performance effect is eliminated when limited or reasonable assurance is provided. This study also identifies an interaction in which positive performance reports with limited, but not reasonable, assurance are perceived to be more believable than reports with no assurance. No differences are identified in the believability of negative performance reports due to the provision or level of assurance.

Results of this study inform academics, practitioners, and standard setters. For academics, theory on firm performance suggests that users find reports depicting negative firm performance to be more believable than reports depicting positive performance (e.g. Williams, 1996; Hutton et al., 2003; Mercer, 2004). This study reinforces firm performance theory when no assurance is present, but provides evidence that assurance on environmental reports serves to eliminate differences in report believability that stem from firm performance. Findings also partially support the notion that the influence of assurance is limited to positive performance conditions (Coram et al., 2009), and that non-expert users do not differentiate between levels of assurance (e.g. Hasan et al., 2003; Hodge et al., 2009). Further, this study 
focuses on whether environmental disclosures are believable to the broader group of users who are not evaluating the information as part of a wealth-maximization decision (Moser and Martin, 2012). From a practitioner standpoint, this study demonstrates that if a firm seeks to use its environmental report to speak to a broader group of stakeholders, limited assurance is an effective tool to enhance report believability when performance is positive. Finally, from a standard-setter perspective, this study calls into question whether users would benefit from formal reporting requirements that have companies explicitly specify when no assurance is provided on environmental disclosures/reports.

The remainder of this paper is organized into four sections. It begins with a review of the relevant literature and hypothesis development. Next appears the research design, which is followed by a description of the results. The study concludes with a summary of key takeaways and insights into the findings.

\section{Background and hypothesis development}

\subsection{Assured CSR reporting in the US}

Globally, the practice of reporting on CSR activities is becoming "standard practice" for firms (KPMG, 2017, p. 4). Even so, there is a lack of widespread structure and conformity in CSR reporting across the US, and firms have a great deal of flexibility in deciding how to disclose such non-financial information (Cohen et al., 2012). For example, using a sample of US firms, Holder-Webb et al. (2009) find that large firms predominantly make these disclosures (from most to least common) on their corporate websites, stand-alone governance documents, mandatory filings, and product fact sheets. Disclosures for smaller firms were found primarily in mandatory filings (Holder-Webb et al., 2009). Given the absence of a widely agreed-upon reporting mechanism and format, Cohen et al. (2012) suggest the credibility of CSR disclosures would benefit from external assurance.

The number of large firms issuing assured CSR reports is on the rise (Green and Zhou, 2013; Junior et al., 2014; KPMG, 2017). Although the level of assured CSR reporting in the US currently lags behind that seen in many other countries (KPMG, 2017), CSR initiatives are becoming increasingly popular (Ballou et al., 2012) and US accounting firms are beginning to invest in CSR services (Gunther, 2010; Foster, 2012; KPMG, 2013). It is therefore not surprising that the US has witnessed a recent increase in the number of assured CSR reports (GRI, 2014b). At the same time, Peters and Romi (2014) have found an increase in the valuerelevance of CSR assurance provided by accountants. The evolving CSR environment in the US has also impacted standard-setters.

The American Institute of Certified Public Accountants (AICPA) issues and maintains the US attestation standards related to verification of non-financial information, including CSR disclosures. Recently, the AICPA's Auditing Standards Board (ASB) completed the Attestation Clarity Project, which clarified and recodified the US attestation standards. The resulting standards are similar to the standards of the International Auditing and Assurance Standards Board (IAASB) that issues International Standards on Assurance Engagements (ISAEs). However, full convergence to IAASB standards did not occur due to "the US profession's experience with the attestation standards during the past 25 years" and the "inconsistencies with other US professional standards" that would have resulted (AICPA, 2013a, p. 6). Of particular interest to this study, the clarified US attestation standards now echo ISAEs and define the two levels of assurance in attestation engagements as being either limited or reasonable[2]. Reasonable assurance is the highest level of assurance currently offered and is provided when an examination is performed, while limited assurance is provided as part of a review (AICPA, 2016). Further, reasonable assurance is positively expressed as an opinion (i.e. "we believe that. .."), whereas limited assurance is negatively expressed as a conclusion (i.e. "nothing came to our attention that. ..") (AICPA, 2016). 
One reason firms might seek independent assurance on their CSR disclosures is to influence report users' perceptions of those reports (cf. Simnett et al., 2009; GRI, 2014b; Junior et al., 2014). The next section considers the influence of assurances like those defined by the AICPA.

\subsection{Impact of assurance on reported information}

Simnett et al. (2009) point out that assurance is not free and is purchased when the benefits presumably outweigh the costs. The benefits of assuring a CSR report may include enhancing disclosure credibility, building corporate reputation, increasing user confidence in the (completeness of) disclosed information, and reducing information asymmetry (Holder-Webb et al., 2009; Simnett et al., 2009; Boiral and Gendron, 2011; Pflugrath et al., 2011; Junior et al., 2014; Cho et al., 2014; Casey and Grenier, 2015; Cohen and Simnett, 2015). Assurance of CSR information is also associated with increased environmental reputation (Birkey et al., 2016), and can enhance the quality of environmental reports in the eyes of stakeholders (Moroney et al., 2012). Investors have also been shown to consider the reliability of sustainability information in assessing a company's market value (Lackmann et al., 2012). Finally, Wong and Millington (2014) find that stakeholders demand CSR assurance when they assess the value of the CSR information to be high and when they believe the representational faithfulness of the disclosures to be low. In summary, CSR assurance is an important tool for management to use in shaping their reputation and to combat the uncertainty users may feel when reviewing CSR reports.

Prior research examines the use of different assurers of CSR information. While not unanimous (e.g. Wong and Millington, 2014), the extant research demonstrates the importance of obtaining assurance from accountants/accounting firms. For example, accountants are more cautious, limited in approach, and offer lower levels of assurance than consultant assurers, which might relate to the accounting profession's robust reporting frameworks and assurance/attestation standards, as well as its rules on independence and professional conduct (O'Dwyer and Owen, 2005). Studies have also found that accounting firms provide the highest quality of assurance on CSR reports (Perego and Kolk, 2012; Casey and Grenier, 2015), that assurance from accountants is more trustworthy, expert, and credible (Pflugrath et al., 2011), and that more expert environmental committees (on the board of directors) prefer CSR assurance from accounting firms (Peters and Romi, 2014). Further, Hodge et al. (2009) find that users perceive CSR reports with reasonable (but not limited) assurance to be more credible when issued by an accounting firm rather than by a specialist consultant firm. Finally, in speaking about the success of companies strategically integrating internal functions with CSR initiatives, Ballou et al. (2012) find that "obtaining assurance is associated with strategic integration, especially when provided by a public accounting firm" (p. 267).

Given the benefits of CSR assurance described to this point, it is also necessary to highlight the body of work that questions the value of this assurance. Boiral and Gendron (2011) challenge CSR assurance engagements as having structural deficiencies and lacking appropriate rigor. O'Dwyer and Owen (2005) raise concerns over management's involvement in the assurance process and question the independence of assurance providers. Green and $\mathrm{Li}$ (2011) document an expectation gap in the responsibilities perceived by preparers and assurers when issuing greenhouse gas emissions reports to stakeholders. Michelon et al. (2015) find that assurance of CSR disclosures is used more to manage corporate image rather than to enhance the accountability of reported information. Finally, Talbot and Boiral (2018) study the energy sector and find widespread issues with CSR disclosures that do not comply with the GRI guidelines, even after an audit by third-party accountants. Collectively, these findings challenge the quality of CSR disclosures/reports, even when they are accompanied by external assurance. 


\subsection{Levels of assurance}

As alluded to with the findings of Hodge et al. (2009), a discussion of assurance on CSR information provided by professional accountants would not be complete without considering the two levels of assurance available under the US attestation standards. These levels are limited and reasonable assurance (AICPA, 2016). As previously described, reasonable assurance is delivered with an opinion or positive expression of assurance, while limited assurance is delivered with a conclusion or negative expression of assurance (AICPA, 2016). Studies find that users differentiate between positive and negative expressions of assurance, in that positive provides more assurance (Gay et al., 1998) and makes the underlying information more reliable (Schelluch and Gay, 2006).

It is not clear whether users differentiate between levels of assurance with CSR reporting. Hasan et al. (2003) used a CSR reporting scenario to examine whether shareholders perceive a difference in assurance provided between a high assurance report and four different moderate assurance reports[3]. Their results indicate that users differentiate between high and moderate assurance with three of four examined iterations of a moderate assurance CSR report, including a moderate assurance report with a negative assurance statement. Later, when Hodge et al. (2009) experimented with users' ability to differentiate between levels of assurance provided on CSR reports, they failed to find a main effect for users' confidence and perceptions of credibility with CSR reports. Finally, Rivière-Giordano et al. (2018) identified a penalty for firms that obtain lower levels of assurance on environmental disclosures, such that financial analysts are less likely to recommend companies that obtain lower levels of assurance (rather than no assurance) on environmental disclosures. In sum, these studies fail to establish whether users differentiate between levels of assurance on CSR disclosures and reports.

Low and Boo (2012) conducted an experiment that helped untangle when users differentiate between levels of assurance being conveyed. Specifically, they found that lessinformed users benefit from contrasting statements to distinguish between limited and reasonable assurance. Under the clarified US attestation standards, limited assurance reports refer to the availability of a higher level of assurance (i.e. reasonable assurance). However, reasonable assurance reports make no contrast to the lower level of available assurance (i.e. limited assurance). Under this current reporting format, only more informed users can distinguish the level of assurance being conveyed. As such, Low and Boo (2012) show that having a contrast statement in both the limited and reasonable assurance reports improves less informed users' understanding of the level of assurance being conveyed. This finding is supported by prior research that shows comparative information, when available, is used by decision- makers (e.g. Slovic and MacPhillamy, 1974; Lipe and Salterio, 2000).

\subsection{Firm CSR performance and user expectations of performance}

Given the voluntary nature of CSR reporting, companies primarily make "self-laudatory" or largely positive CSR disclosures (Holder-Webb et al., 2009, p. 517). Signaling theory suggests that firms with positive performance disclose this information to show their elevated commitment to CSR activities (Mahoney et al., 2013), while Moser and Martin and Moser (2016) find that the aim of such disclosures is to receive a positive response from users. However, environmental disclosures do not always align with the true performance of companies.

Research has identified several reporting biases/tactics that firms use when disclosing CSR information. For example, companies with poorer CSR performance tend to provide offsetting favorable disclosures (O'Donovan, 1999; Cho and Patten, 2007), use disclosures with more optimism and less certainty (Cho et al., 2010), disclose less environmental information (Al-Tuwaijri et al., 2004), and disclose environmental capital spending to hedge against political and regulatory concerns (Cho et al., 2012). Studies have also shown that 
annual report disclosures focus on positive rather than on negative environmental results (Deegan and Gordon, 1996), companies underreport negative events (Hughes et al., 2001; Adams, 2004; Boiral, 2013), and companies prosecuted for environmental issues have increased reporting of favorable environmental news around the time of the associated trial (Deegan and Rankin, 1996). Further, Cho et al. (2015a) argue that competing societal and institutional pressures prevent companies from making substantive sustainability disclosures, while Cho et al. (2015b) find that corporate legitimacy drives CSR reporting rather than the desire to provide investors with valuable information. Given this stream of research, it is not surprising that recent calls from practice and the accounting literature indicate a desire for firms to use balanced reporting that includes both positive and negative CSR activities (KPMG and SustainAbility, 2008; Cohen, 2014)[4].

A firm's CSR performance can influence user decision-making (Elliott et al., 2014), and there are several approaches to predict how users will respond to these positive or negative disclosures. One approach suggests users find positive news disclosures to be less credible than negative news disclosures (Williams, 1996; Hutton et al., 2003; Mercer, 2004) and that assurance may only influence user decision-making in positive performance conditions (Coram et al., 2009). However, this would not provide for a robust prediction given there might be a pre-existing user expectation that firms would disclose only positive news in CSR reporting (cf. Verrecchia, 1983; KPMG and SustainAbility, 2008). Further, managers have more incentive to provide positive (rather than negative) disclosures (Verrecchia, 1983; McNichols, 1989). Therefore, an appropriate approach to examine the influence of firm environmental performance on user perceptions of environmental report believability takes into account the expectation that firms will report positive performance.

Persuasion theory offers insight into how individuals react when their expectations of a message are (dis)confirmed. Specifically, individuals are more influenced (persuaded) when they do not expect a messenger to accurately report reality (i.e. the messenger is perceived to have a reporting bias), but then the actual message appears to be truthful and disconfirms these expectations (Eagly et al., 1978). Based on the findings of KPMG and SustainAbility (2008), this study posits that users expect a reporting bias in that firms will primarily disclose positive environmental performance. This is consistent with Verrecchia (1983), who provides that users have rational expectations that management will withhold unfavorable news with discretionary disclosures. Therefore, theory suggests these users will perceive any non-selfinterested (i.e. negative performance) disclosures to be more believable than disclosures of positive performance (Eagly et al., 1978; Williams, 1996; Hutton et al., 2003; Mercer, 2004).

\subsection{Hypotheses}

Based on the preceding discussion, this study tests five hypotheses. First, if users find environmental reports that disclose negative performance to be inherently believable, environmental reports that disclose negative performance will be perceived to be more believable than environmental reports that disclose positive performance, holding constant the level of assurance. Hypothesis 1 formally predicts a main effect for firm performance as follows:

H1. Users will perceive management's environmental report to be more believable in the negative rather than in the positive performance condition across levels of assurance (i.e. none, limited, and reasonable assurance).

The presented literature also provides a theoretical basis that assurance should enhance the perceived believability of environmental reports. However, prior research does not clearly support whether environmental report believability differs when a limited versus reasonable level of assurance is provided. Therefore, H2 and H3 offer separate predictions for main effects related to (1) the provision of assurance, and (2) the level of assurance on perceptions of environmental report believability: 
H2. Users will perceive management's assured environmental report to be more believable than management's non-assured environmental report across firm performance conditions.

H3. Users will not perceive a difference in the believability of management's environmental report when limited versus reasonable assurance is provided across firm performance conditions.

Finally, the discussed literature suggests that the provision/level of assurance should influence users' perceptions of environmental report believability when firms disclose positive, but not negative, performance. Specifically, users should perceive the environmental report to be more believable when it is assured (versus not assured) in a positive performance condition. However, it is unclear in the positive performance condition whether users will perceive the environmental report to be more believable when offered limited assurance (with a contrast statement) versus reasonable assurance (with no contrast statement). The final two hypotheses address these two scenarios within the positive performance condition:

H4. Users will perceive management's assured environmental report to be more believable than management's non-assured environmental report in the positive performance condition.

H5. Users will not perceive a difference in the believability of management's environmental report when limited versus reasonable assurance is provided in the positive performance condition.

See Figure 1 for predicted relationships.

\section{Research design}

\subsection{Participants}

Participants for the study were recruited through a crowdsourcing tool, Amazon Mechanical Turk (MTurk)[5]. To take part in the study, programmed system controls required participants to be located in the US and have a Human Intelligence Task (HIT) acceptance rate of greater than or equal to 90 percent. MTurk allows requestors (i.e. those conducting a study) to review responses from MTurk workers and either approve or deny payment; thus, by requiring a HIT approval rate greater than or equal to 90 percent, the requestor is trying to

Figure 1.

Predicted effects of relative firm environmental performance and assurance provided on the believability of management's environmental report

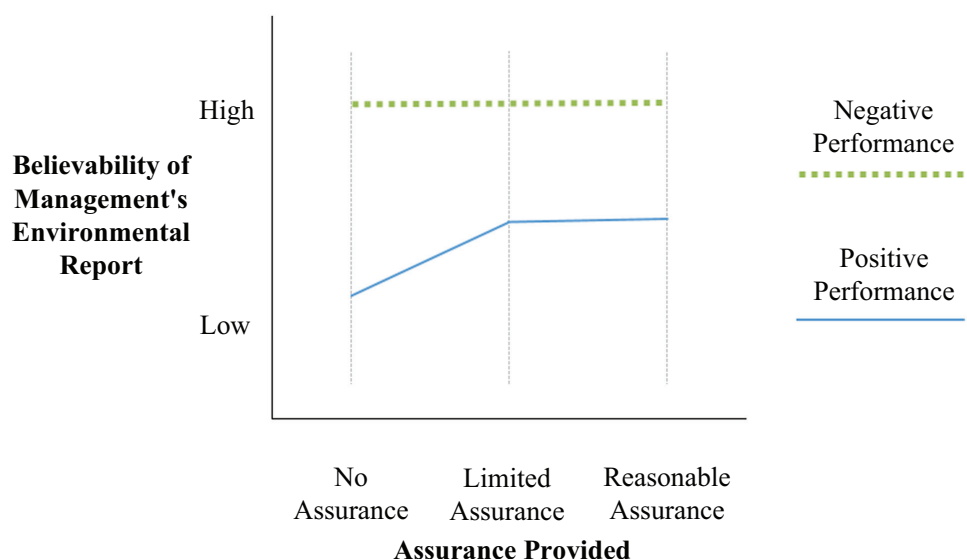

Assurance Provided 
attract participants with a proven record of submitting acceptable HITs. Participants were also asked whether they (1) were at least 18 years old, (2) had purchased stock in the past 12 months, and (3) had not bought/sold/traded stock as part of their employment responsibilities (cf. Ozlanski, 2013); only those responding "Yes" to each of these three questions were given access to the instrument. Based on these requirements, participants were individuals with general business knowledge and experience with investing activities, and served as proxies for non-expert users of environmental reports[6].

In total, 260 participants completed the experiment, but only 153 of the responses could be analyzed. Participants were not analyzed if they did not pass all four comprehension check questions, did not have a worker ID appear in the MTurk output (i.e. a unique ID used to identify participants), or did not answer any of the dependent variable questions. The four multiple-choice comprehension check questions included the following. (1) As described in the Independent Accountant's Report, did the accountant provide the same verification (i.e. assurance) on all four greenhouse gas emission indicators? (2) Who prepared the Independent Accountant's Report? (3) Did the Independent Accountant's Report relate to TWBC's financial statements or greenhouse gas emissions? (4) How many methods to verify (i.e. assure) TWBC's greenhouse gas emissions are described in the Independent Accountant's Report?

Participants were also removed for spending less than five minutes on the experiment. This action was to disqualify participants that clearly did not complete the experiment, and likely accessed and then quickly exited the survey just to receive payment. Based on this requirement, three participants who spent an average of $6.3 \mathrm{~s}$ on the experiment were removed. Finally, participants were removed if they did not pass a manipulation check question about the firm's relative environmental performance. The manipulation check question asked the following: "How did you perceive TWBC's performance in controlling greenhouse gas emissions as compared to the industry average?" Participants responded using a fully labeled seven-point Likert scale with endpoints Much Worse $(-3)$ and Much Better $(+3)$. Participants in the positive performance condition were removed for responses from $(-3)$ to $(0)$, while participants in the negative performance condition were removed for responses from $(0)$ to $(+3)$. The study did not use a qualifying manipulation check on the level of perceived assurance. Rather, it sought to measure perceptions of limited and reasonable assurance using the AICPA's recommended verbiage for the Independent Accountant's Report. These results appear later in Section 4.2, Analyses of other dependent measures.

For the 153 useable participants, the experiment had an average duration of $26.0 \mathrm{~min}$ with an SD of $17.6 \mathrm{~min}$ (low $=6.2 \mathrm{~min}$; high $=85.4 \mathrm{~min}$ ). Each participant was paid $\$ 2.50$, which resulted in an effective hourly rate of $\$ 5.77$, well above the effective hourly rate of $\$ 3.75$ documented in Rennekamp (2012). Participants' demographic information appears in Table I. Of the 153 accepted participants: (1) 57.2 percent were male and 42.8 percent were female (one participant did not respond to the gender question, so this is based on a denominator of 152), (2) 38.6 percent were in the age group of 35-54 and another 34.6 percent were in the age group of 26-34 years, and (3) 55.6 percent had at least a four-year college degree. All 153 accepted participants completed the case study in one sitting, and three of the accepted participants reported to be (or at one time were) certified public accountants (CPAs).

\subsection{Experimental task and materials}

This study uses a $2 \times 3$ between-subjects design in which relative firm environmental performance (positive, negative) and assurance provided (none, limited, reasonable) are manipulated. Figure 2 provides a flowchart of the experimental procedures. The experiment was administered online using Qualtrics, and participants were randomly assigned to a group based on an automated routine in Qualtrics. Upon accessing the study, participants reviewed the experimental instructions and then received background information on the 
Table I.

Participant demographic information
Figure 2.

Flowchart of experimental procedures

\begin{tabular}{|c|c|c|c|c|c|c|c|}
\hline \multirow[b]{2}{*}{ Question } & \multirow[b]{2}{*}{ Response options } & \multicolumn{2}{|c|}{ All participants } & \multicolumn{2}{|c|}{$\begin{array}{l}\text { Accepted } \\
\text { participants }\end{array}$} & \multicolumn{2}{|c|}{$\begin{array}{l}\text { Rejected } \\
\text { participants }\end{array}$} \\
\hline & & Count & $\begin{array}{l}\% \text { of } \\
\text { total }\end{array}$ & & $\begin{array}{l}\% \text { of } \\
\text { total }\end{array}$ & Count & $\begin{array}{l}\% \text { of } \\
\text { total }\end{array}$ \\
\hline What is your gender? & Male & 147 & $57.0 \%$ & 87 & $57.2 \%$ & 60 & $56.6 \%$ \\
\hline \multirow{2}{*}{ A } & Female & 111 & $43.0 \%$ & 65 & $42.8 \%$ & 46 & $43.4 \%$ \\
\hline & & 258 & $100.0 \%$ & 152 & $100.0 \%$ & 106 & $100.0 \%$ \\
\hline \multirow{6}{*}{ How old are you? } & $18-25$ & 65 & $25.0 \%$ & 27 & $17.6 \%$ & 38 & $35.5 \%$ \\
\hline & $26-34$ & 93 & $35.8 \%$ & 53 & $34.6 \%$ & 40 & $37.4 \%$ \\
\hline & $35-54$ & 82 & $31.5 \%$ & 59 & $38.6 \%$ & 23 & $21.5 \%$ \\
\hline & $55-64$ & 15 & $5.8 \%$ & 10 & $6.5 \%$ & 5 & $4.7 \%$ \\
\hline & 65 or over & 5 & $1.9 \%$ & 4 & $2.6 \%$ & 1 & $0.9 \%$ \\
\hline & & 260 & $100.0 \%$ & 153 & $100.0 \%$ & 107 & $100.0 \%$ \\
\hline \multirow{4}{*}{$\begin{array}{l}\text { What is the highest } \\
\text { level } \\
\text { of education you have } \\
\text { completed? }\end{array}$} & $\begin{array}{l}<4 \text {-years College } \\
\text { Deoree }\end{array}$ & 129 & $49.6 \%$ & 68 & $44.4 \%$ & 61 & $57.0 \%$ \\
\hline & $\begin{array}{l}\text { 4-years college } \\
\text { degree }\end{array}$ & 96 & $36.9 \%$ & 61 & $39.9 \%$ & 35 & $32.7 \%$ \\
\hline & $\begin{array}{l}\text { Postgrad or some } \\
\text { postgrad }\end{array}$ & 35 & $13.5 \%$ & 24 & $15.7 \%$ & 11 & $10.3 \%$ \\
\hline & & 260 & $100.0 \%$ & 153 & $100.0 \%$ & 107 & $100.0 \%$ \\
\hline
\end{tabular}

Note(s): A-Two of the 260 participants did not respond to this question; one was an accepted participant and one was a rejected participant

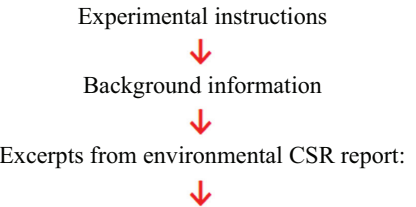

Part 1: Firm's disclosure and discussion of greenhouse gas emissions

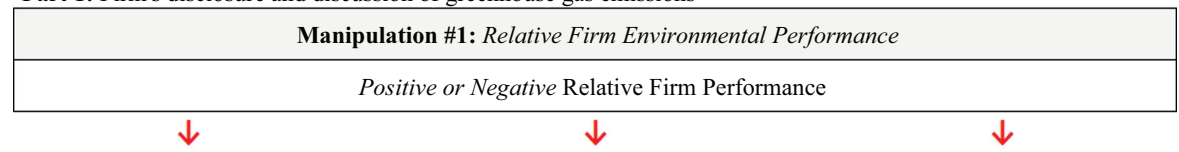

Part 2: Independent accountant's report on greenhouse gas emissions

\begin{tabular}{|l|c|c|c|}
\hline \multicolumn{3}{|c|}{ Manipulation \#2: Assurance Provided } \\
\hline \multirow{2}{*}{ No Assurance } & & Limited Assurance & Reasonable Assurance \\
& &
\end{tabular}

Dependent Variable and Comprehension Check questions

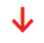

Demographic questions

fictitious Tasty Water Beverage Company (TWBC). After reviewing the background information, participants viewed excerpts from the most recent TWBC environmental CSR report. The report consisted of (1) a report cover page, (2) TWBC presentation and discussion of its greenhouse gas emissions for the year, including its performance in relation to the food and beverage industry, and (3) an independent accountant's report. TWBC was intentionally placed in the food and beverage industry, as KPMG (2013) indicates this industry performs at the global average in terms of the quality and number of CSR reports issued. Further, 
TWBC's presentation and discussion of greenhouse gas emissions highlighted four environmental indicators defined by the GRI G4 framework (GRI, 2013): G4-EN15: Direct greenhouse gas emissions; G4-EN16: Energy indirect greenhouse gas emissions; G4-EN17: Other indirect greenhouse gas emissions; and G4-EN19: Reduction of greenhouse gas emissions (GRI, 2014c)[7]. The GRI G4 framework is the most commonly used CSR reporting framework worldwide (KPMG, 2017). The study focuses on greenhouse gas emission disclosures because these are the predominant environmental CSR metrics assured in the US and have the most robust technical guidance for attestations from independent accountants (AICPA, 2013b; AICPA, 2017).

As part of TWBC's presentation and disclosure of the selected GRI G4 indicators, each indicator was included in a summary table showing the performance of TWBC, the food and beverage industry average, and TWBC's percentage difference from the industry average. TWBC greenhouse gas emission levels reflect those of a company approximately 5 percent of the size (in terms of emissions) of The Coca-Cola Company or PepsiCo. These same companies were used as a guide to establish differences in emission levels between EN15, EN16, and EN17 (i.e. EN16 emissions are approximately double the EN15 emissions, and EN17 emissions are approximately 1.82 times the EN15 emissions). Consistent with Elliott et al. (2014), TWBC's performance was manipulated with respect to performance against the industry average to establish positive or negative relative environmental performance. Indicators EN15, EN16, and EN17 varied from the industry average by approximately - 60 percent or +60 percent in the positive and negative performance conditions. Indicator EN19 was presented as a percentage reduction in emissions of approximately +60 percent and -60 percent (i.e. an increase) in the positive and negative performance conditions. The magnitude of differences to establish positive and negative performance is consistent with the approach used by Elliott et al. (2014).

The assurance manipulation (for participants in an assurance condition) appeared in the final excerpt from TWBC's environmental CSR report: the independent accountant's report. Here, a large international accounting firm provided either limited or reasonable assurance on the disclosed greenhouse gas emission indicators. The general format and verbiage of the independent accountant's report was guided by examples provided in SOP 13-1, Attest Engagements on Greenhouse Gas Emissions Information (AICPA, 2013b), and the leveraged verbiage remains consistent with the AICPA's Attestation Engagements on Sustainability Information Guide (Including Greenhouse Gas Emissions Information) and the clarified US attestation standards (AICPA, 2016; AICPA, 2017). Participants were also provided a summary table of the assured indicators within the independent accountant's report. Please refer to the Appendix for excerpts from the experimental materials.

\subsection{Dependent variables}

After viewing the independent accountant's report, participants responded to several dependent variables well established in the accounting literature. As discussed, the primary measure of interest is environmental report believability. To accomplish this task, three dependent variables employed by Hodge et al. (2009) were used to create an index to measure this underlying construct. These items included (with endpoints shown) the following: (1) How reliable do you find TWBC's representations made in the Company's 2014 Environmental Sustainability Report ( -3 Strongly Not Reliable, +3 Strongly Reliable), (2) How credible do you find TWBC's disclosures about greenhouse gas emissions ( -3 Strongly Not Credible, +3 Strongly Credible), and (3) How confident are you that Tasty Water Beverage Company's 2014 Environmental Sustainability Report represents the true performance of the company with respect to greenhouse gas emissions ( -3 Strongly Not Confident, +3 Strongly Confident)? Based on participants' responses, these items have a Cronbach's alpha score of 0.924 , meaning there is strong evidence they measure the same 
underlying construct, which, in this study, is referred to as report believability. Only after the participants had reviewed the experimental materials and responded to the primary dependent variables, the study asked about the attractiveness of TWBC as a potential investment opportunity. Finally, the study also asked a series of questions to be analyzed as possible covariates, including: (1) the perceived assurance provided by the accounting firm (Hasan et al., 2003), (2) the impact of assurance on the credibility of results, and (3) the perceived credibility and trustworthiness of management (cf. Mercer, 2004; Beyer et al., 2010; Pflugrath et al., 2011). Responses to these items were collected with a questionnaire at the end of the study that used seven-point Likert scales $(0-6$, or -3 to +3 depending on the question) with all points labeled and endpoints primarily appearing as Strongly Disagree / Strongly Agree[8].

\section{Results}

\subsection{Hypotheses tests}

Summary statistics for the index used to measure report believability are presented in Table II, and suggest that participants found management's environmental report to be generally believable. Marginal means show that participants rated the environmental report to be most believable with reasonable assurance (1.803), followed by no assurance (1.773) and then limited assurance (1.768). As expected, participants rated the report to be more believable in the negative (1.858) than in the positive (1.702) performance condition. A review of means by cell reveals a pattern similar to that hypothesized, with the exception of limited assurance in both the positive and negative performance conditions. Specifically, participants in the positive performance condition rated the report to be most believable with limited assurance, while participants in the negative performance condition rated the report to be least believable with limited assurance. Figure 3 reinforces the unexpected results for limited assurance.

Table II.

Cell means, standard deviations, and sample sizes with believability of management's environmental report as the dependent variable

\begin{tabular}{lcccc}
\hline & \multicolumn{3}{c}{ Mean, (SD), Sample Size } \\
Assurance \\
Firm performance & No assurance & $\begin{array}{c}\text { Limited } \\
\text { Positive }\end{array}$ & Reasonable & Marginal means \\
\hline Negative & $1.4444(1.1139)$ & $2.0800(0.5117)$ & $1.6481(0.9733)$ & $1.7018(0.9515)$ \\
& $n=33$ & $n=25$ & $n=18$ & $n=76$ \\
Marginal Means & $2.1010(0.7383)$ & $1.3968(1.5406)$ & $1.9365(0.9523)$ & $1.8578(1.1003)$ \\
& $n=33$ & $n=21$ & $n=21$ & $n=75$ \\
& $1.7727(0.9943)$ & $1.7681(1.1458)$ & $1.8034(0.9604)$ & Total \\
& $n=66$ & $n=46$ & $n=39$ & $n=151$
\end{tabular}

Note(s): This study used three dependent variables to create an index for whether participants believed the information provided in the environmental report. Results of the believability index are reported in this table The three items have high reliability (Cronbach's alpha of 0.924), and each item was measured using a fully labeled seven-point Likert scale with endpoints as shown below:

(1) How reliable do you find TWBC's representations made in the Company's 2014 Environmental Sustainability Report? ( -3 , Strongly Not Reliable, +3 , Strongly Reliable)

(2) How credible do you find TWBC's disclosures about greenhouse gas emissions? ( -3 , Strongly Not Credible, +3 , Strongly Credible)

(3) How confident are you that Tasty Water Beverage Company's 2014 Environmental Sustainability Report represents the true performance of the company with respect to greenhouse gas emissions? $(-3$, Strongly Not Confident, +3 , Strongly Confident)

Note that the total number of participants shown in this table is 151 , as two participants did not answer all three items and were therefore removed from this analysis 
Prior to testing hypotheses, the data were reviewed for conformity with the basic assumptions of ANOVA, including independence of observations, normal distribution of the dependent variables, and homogeneity of variance (Keppel, 1991, p. 97). Based on this review, the data did not sufficiently achieve normal distribution or homogeneity of variance. As such, the statistical analyses used to test hypotheses are Mann-Whitney $U$ tests, the nonparametric equivalent of $t$-tests (Corder and Foreman, 2014).

As described, this study uses five hypotheses to predict perceptions of environmental report believability; $\mathrm{H} 1, \mathrm{H} 2$, and $\mathrm{H} 3$ predict main effects of relative firm performance and use/ level of assurance, while $\mathrm{H} 4$ and $\mathrm{H} 5$ predict relationships within the positive performance condition. Hypothesis 1 predicts a main effect in that users perceive management's environmental report to be more believable in the negative than in the positive performance condition across levels of assurance. Based on a Mann-Whitney $U$ test comparing the marginal means of performance conditions, the mean rank is significantly higher in the negative performance condition than in the positive performance condition $(p=0.047$, onetailed). This serves as evidence that users perceive negative environmental performance reports to be more believable than positive performance reports. See Panel A of Table III for supporting analyses.

Hypothesis 2 predicts a main effect for assurance, such that users perceive management's assured environmental report to be more believable than a non-assured report. To test this, the no assurance cell was first compared to both assurance cells (i.e. combined limited and reasonable). Results indicate there is not a significant difference in the mean rank of assured versus non-assured cells ( $p=0.326$, one-tailed). The next test compared the no assurance cell separately against the limited and reasonable assurance cells. Again, results indicate there are not significant differences in mean ranks between no assurance and limited assurance $(\phi=0.316$, one-tailed), and no assurance versus reasonable assurance ( $\phi=0.397$, one-tailed). As such, there does not appear to be a main effect for the use of assurance. See Panel B of Table III for supporting analyses. For H3, a null hypothesis is used to predict the lack of a main effect, such that users do not perceive a difference in environmental report believability when provided limited versus reasonable assurance. Results show there is not a significant difference in mean ranks between limited and reasonable assurance ( $\phi=0.881$, two-tailed), and thus $\mathrm{H} 3$ cannot be rejected. Based on the testing of $\mathrm{H} 2$ and $\mathrm{H} 3$, there is no evidence that users perceive a difference in environmental report believability based solely on the use or level of assurance.

For H4 and H5, this study relies on the theory that the impact of assurance on user decision-making might be context-specific to a positive performance condition (Coram et al.,

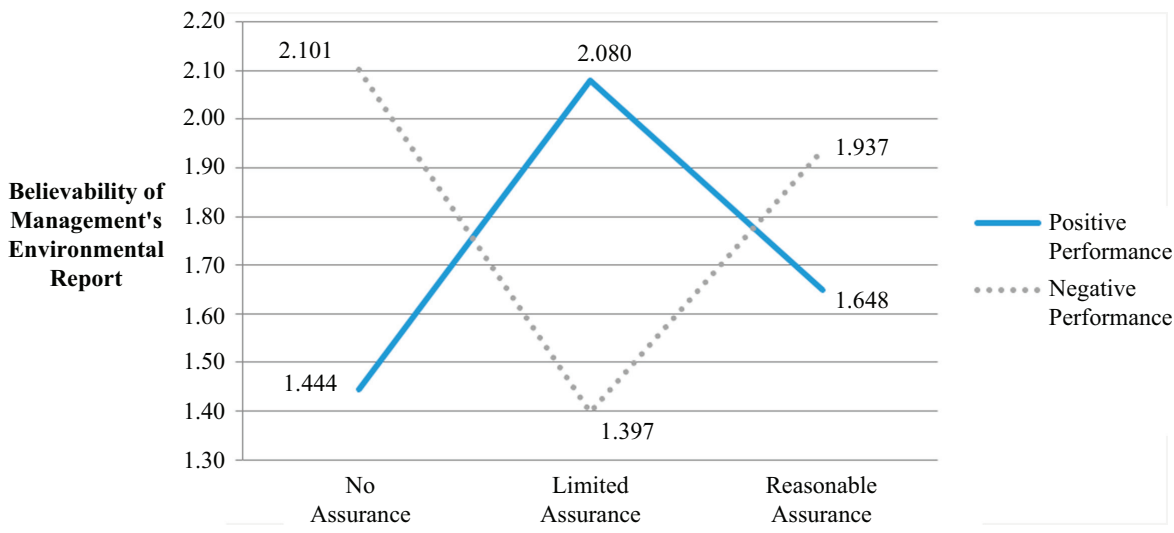

Figure 3.

Effects of relative firm environmental performance and assurance provided on the believability of management's environmental report 


\begin{tabular}{|c|c|c|c|c|c|c|c|}
\hline $\begin{array}{l}\text { Panel A: Main effects } \\
\text { Effect of firm } \\
\text { performance }\end{array}$ & $\begin{array}{l}\text { firm performa } \\
\text { Source of } \\
\text { variation }\end{array}$ & $N$ & $\begin{array}{l}\text { Mean } \\
\text { rank }\end{array}$ & $\begin{array}{l}\text { Sum of } \\
\text { rank }\end{array}$ & $U$-value & $Z$ & $\begin{array}{c}p \text {-value } \\
\text { (one-tailed) }\end{array}$ \\
\hline \multirow{2}{*}{$\begin{array}{l}\text { Across all assurance } \\
\text { conditions }\end{array}$} & Positive & 76 & 70.11 & 5328.0 & 3298.0 & \multirow[t]{2}{*}{-1.665} & \multirow[t]{2}{*}{0.047} \\
\hline & $\begin{array}{l}\text { Negative } \\
\text { performance }\end{array}$ & 75 & 81.97 & 6148.0 & 2402.0 & & \\
\hline
\end{tabular}

Panel B: Main effects of level of assurance (H2 and H3)

Effect of level of

\begin{tabular}{|c|c|c|c|c|c|c|c|}
\hline $\begin{array}{l}\text { Effect of level of } \\
\text { assurance }\end{array}$ & Source of variation & $N$ & $\begin{array}{c}\text { Mean } \\
\text { rank }\end{array}$ & $\begin{array}{c}\text { Sum of } \\
\text { rank }\end{array}$ & $U$-value & $Z$ & $\begin{array}{c}p \text {-value } \\
\text { (one-tailed) }\end{array}$ \\
\hline Across both & No assurance & 66 & 74.18 & 4896.0 & 2925.0 & \multirow[t]{2}{*}{0.448} & \multirow[t]{2}{*}{0.326} \\
\hline $\begin{array}{l}\text { performance } \\
\text { conditions }\end{array}$ & $\begin{array}{l}\text { Assurance (limited } \\
\text { and reasonable) }\end{array}$ & 85 & 77.41 & 6580.0 & 2685.0 & & \\
\hline Across both & No assurance & 66 & 55.27 & 3648.0 & 1599.0 & \multirow[t]{2}{*}{-0.476} & \multirow[t]{2}{*}{0.316} \\
\hline $\begin{array}{l}\text { performance } \\
\text { conditions }\end{array}$ & Limited assurance & 46 & 58.26 & 2680.0 & 1437.0 & & \\
\hline Across both & No assurance & 66 & 52.41 & 3459.0 & 1326.0 & \multirow[t]{2}{*}{-0.255} & \multirow[t]{2}{*}{0.397} \\
\hline $\begin{array}{l}\text { performance } \\
\text { conditions }\end{array}$ & $\begin{array}{l}\text { Reasonable } \\
\text { assurance }\end{array}$ & 39 & 54.00 & 2106.0 & 1248.0 & & \\
\hline Across both & Limited assurance & 46 & 43.37 & 1995.0 & 880.0 & \multirow[t]{2}{*}{0.146} & \multirow[t]{2}{*}{$0.881^{\mathrm{a}}$} \\
\hline $\begin{array}{l}\text { performance } \\
\text { conditions }\end{array}$ & $\begin{array}{l}\text { Reasonable } \\
\text { assurance }\end{array}$ & 39 & 42.56 & 1660.0 & 914.0 & & \\
\hline
\end{tabular}

Panel C: Differences due to assurance within the positive performance condition (H4 and H5)

\begin{tabular}{|c|c|c|c|c|c|c|c|}
\hline Effect within: & Source of variation & $N$ & $\begin{array}{l}\text { Mean } \\
\text { rank }\end{array}$ & $\begin{array}{l}\text { Sum of } \\
\text { rank }\end{array}$ & $U$-value & $Z$ & $\begin{array}{c}p \text {-value } \\
\text { (one-tailed) }\end{array}$ \\
\hline \multirow{2}{*}{$\begin{array}{l}\text { Positive } \\
\text { performance } \\
\text { condition }\end{array}$} & No assurance & 33 & 33.06 & 1091.0 & 889.0 & \multirow[t]{2}{*}{1.876} & \multirow[t]{2}{*}{0.030} \\
\hline & $\begin{array}{l}\text { Assurance (limited } \\
\text { and reasonable) }\end{array}$ & 43 & 42.67 & 1835.0 & 530.0 & & \\
\hline \multirow{2}{*}{$\begin{array}{l}\text { Positive } \\
\text { performance } \\
\text { condition }\end{array}$} & No assurance & 33 & 25.00 & 825.0 & 561.0 & \multirow{2}{*}{-2.324} & \multirow[t]{2}{*}{0.010} \\
\hline & Limited assurance & 25 & 35.44 & 886.0 & 264.0 & & \\
\hline \multirow{2}{*}{$\begin{array}{l}\text { Positive } \\
\text { performance } \\
\text { condition }\end{array}$} & No assurance & 33 & 25.06 & 827.0 & 328.0 & \multirow[t]{2}{*}{-0.601} & \multirow[t]{2}{*}{0.274} \\
\hline & $\begin{array}{l}\text { Reasonable } \\
\text { assurance }\end{array}$ & 18 & 27.72 & 499.0 & 266.0 & & \\
\hline \multirow{2}{*}{$\begin{array}{l}\text { Positive } \\
\text { performance } \\
\text { condition }\end{array}$} & Limited assurance & 25 & 24.56 & 614.0 & 161.0 & \multirow[t]{2}{*}{1.563} & \multirow[t]{2}{*}{$0.119^{\mathrm{a}}$} \\
\hline & $\begin{array}{l}\text { Reasonable } \\
\text { assurance }\end{array}$ & 18 & 18.44 & 332.0 & 289.0 & & \\
\hline
\end{tabular}

Panel D: Differences due to assurance within the negative performance condition

Table III.

Nonparametric MannWhitney $U$ tests with believability of management's environmental report as the dependent variable
Source of Mean Sum of $p$-value

Effect within: variation $U$-value

$985.5 \quad 268.5$

$\begin{array}{lllll}\text { Limited } & 21 & 23.79 & 499.5 & 424.5\end{array}$

condition

Negative performance condition

Negative performance condition
No assurance

assurance

No assurance

Reasonable assurance

Limited assurance Reasonable assurance

$\begin{array}{llll}33 & 28.06 & 926.0 & 328.0 \\ 21 & 26.62 & 559.0 & 365.0\end{array}$

0.749

$\begin{array}{lllll}21 & 19.55 & 410.5 & 261.5 & -1.019\end{array}$

0.308

$\begin{array}{llll}21 & 23.45 \quad 492.5 & 179.5\end{array}$ (two-tailed) 


\begin{tabular}{llcccccc}
\multicolumn{2}{l}{ Panel E: Differences due to firm performance within } & \multicolumn{7}{l}{ the assurance conditions } & & \\
Effect within: & $\begin{array}{l}\text { Source of } \\
\text { variation }\end{array}$ & $N$ & $\begin{array}{l}\text { Mean } \\
\text { rank }\end{array}$ & $\begin{array}{c}\text { Sum of } \\
\text { rank }\end{array}$ & $U$-value & $Z$ & $\begin{array}{c}p \text {-value } \\
\text { (two-tailed) }\end{array}$ \\
\hline $\begin{array}{l}\text { No assurance } \\
\text { condition }\end{array}$ & $\begin{array}{l}\text { Positive } \\
\text { performance }\end{array}$ & 33 & 27.68 & 913.5 & 736.5 & -2.456 & 0.014 \\
& $\begin{array}{l}\text { Negative } \\
\text { performance }\end{array}$ & 33 & 39.32 & 1297.5 & 352.5 & & \\
$\begin{array}{l}\text { Limited assurance } \\
\text { condition }\end{array}$ & $\begin{array}{l}\text { Positive } \\
\text { performance } \\
\text { Negative }\end{array}$ & 25 & 25.42 & 635.5 & 214.5 & 1.048 & 0.294 \\
$\begin{array}{l}\text { performance } \\
\text { Reasonable assurance } \\
\text { condition }\end{array}$ & $\begin{array}{l}\text { Positive } \\
\text { performance }\end{array}$ & 18 & 17.22 & 310.0 & 239.0 & 1.395 & 0.165 \\
& $\begin{array}{l}\text { Negative } \\
\text { performance }\end{array}$ & 21 & 22.38 & 470.0 & 139.0 & &
\end{tabular}

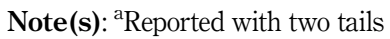

This study used three dependent variables to create an index for whether participants believed the information provided in the environmental report. Results of the believability index are reported in this table. The three items have high reliability (Cronbach's alpha of 0.924), and each item was measured using a fully labeled sevenpoint Likert scale with endpoints as shown below:

(1) How reliable do you find TWBC's representations made in the Company's 2014 Environmental Sustainability Report? (-3, Strongly Not Reliable, +3 , Strongly Reliable)

(2) How credible do you find TWBC's disclosures about greenhouse gas emissions? ( -3 , Strongly Not Credible, +3 , Strongly Credible)

(3) How confident are you that Tasty Water Beverage Company's 2014 Environmental Sustainability Report represents the true performance of the company with respect to greenhouse gas emissions? $(-3$, Strongly Not Confident, +3 , Strongly Confident)

As discussed, the data in this study do not conform to two basic assumptions of ANOVA: normal distribution and homogeneity of variance. As such, the statistical analyses used to test hypotheses are Mann-Whitney $U$-tests, which are the nonparametric equivalent of $t$-tests (Corder and Foreman, 2014). Given the mechanics of Mann-Whitney $U$-tests, the mean rank for a specific condition (e.g. limited assurance, positive performance) will likely differ based on the condition it is being compared against. This is because the mean rank for a specific condition is determined based on the rank of its individual scores (i.e. participant responses in that condition) only after being combined with the scores from the comparison condition (Corder and Foreman, 2014)

Note that the total number of participants analyzed in this table is 151, as two participants did not answer all three items and were therefore removed from this analysis

Table III.

2009), and that users might differentiate between limited and reasonable assurance due to a contrast statement in the limited assurance report (Low and Boo, 2012). However, it is unclear whether users should find management's environmental report to be more believable in the positive performance condition with limited or reasonable assurance. Hypothesis 4 predicts that users perceive environmental reports to be more believable when assured versus not assured for firms with positive environmental performance. To test this, the no assurance cell was first compared to both assurance cells (i.e. combined limited and reasonable). Results show that the mean rank of assured cells is significantly higher than the no assurance cell $(p=0.030$, one-tailed). The next test compared the no assurance cell separately against the limited and reasonable assurance cells. Results show that environmental reports are perceived to be more believable with limited assurance rather than no assurance $(\phi=0.010$, one-tailed), but there is no difference in believability between no assurance and reasonable assurance ( $\phi=0.274$, one-tailed). See Panel C of Table III for supporting analyses. To complete the comparisons in the positive performance condition, $\mathrm{H} 5$ predicts no difference in the believability of environmental reports with limited versus reasonable assurance. Results 
show that users do not perceive a difference in report believability when limited versus reasonable assurance is provided in a positive performance condition ( $\phi=0.119$, two-tailed). See Panel C of Table III for supporting analyses. The results of $\mathrm{H} 4$ and $\mathrm{H} 5$ provide evidence that in a positive performance condition, users perceive environmental reports to be more believable when accompanied by limited rather than no assurance.

Given the findings for $\mathrm{H} 4 / \mathrm{H} 5$ and the unexpected pattern of means displayed in Figure 3, cells in the negative performance condition were also analyzed for differences. Results show no significant differences within the negative performance condition, such that the believability of management's environmental report does not differ when accompanied by (1) no assurance versus limited assurance ( $\phi=0.168$, two-tailed), (2) no assurance versus reasonable assurance ( $\phi=0.0749$, two-tailed), or (3) limited assurance versus reasonable assurance ( $\phi=0.308$, two-tailed). While the pattern of means appears to be just the opposite of those identified in the negative performance condition, there are no significant differences within the negative performance condition. See Panel D of Table III for supporting analyses. These results seem to support previous findings that the impact of assurance might be context-specific to positive performance conditions (Coram et al., 2009). In summary, the findings for $\mathrm{H} 4 / \mathrm{H} 5$ indicate an increase in environmental report believability when limited rather than no assurance is provided in a positive performance condition, yet no differences in believability are identified within the negative performance condition.

Considering the behavior of the limited assurance cells and the pattern of means displayed in Figure 3, testing was also performed on the effect of firm performance within specific assurance conditions. Results show that negative performance reports are perceived to be significantly more believable than positive performance reports when no assurance is provided $(\phi=0.014$, two-tailed). However, the differences in believability between performance conditions disappear when either limited $(\phi=0.294$, two-tailed) or reasonable $(p=0.165$, two-tailed) assurance is provided. See Panel E of Table III for supporting analyses. These findings seem to indicate that firm performance impacts perceptions of report believability, but only when assurance is not provided.

\subsection{Analyses of other dependent measures}

As mentioned previously, this study also measured several other dependent variables well established in the accounting literature. These include (1) the attractiveness of TWBC as a potential investment opportunity, (2) perceived assurance provided by the accounting firm (Hasan et al., 2003), (3) the impact of assurance on the credibility of results, and (4) the perceived credibility and trustworthiness of management (cf. Mercer, 2004; Beyer et al., 2010; Pflugrath et al., 2011). The attractiveness as a potential investment was collected and analyzed to determine how users not tasked with assessing an environmental report as a shareholder/investor would later evaluate it as a potential investment opportunity (i.e. impact on behavior). The items on perceived/impact of assurance and management were collected to serve as possible covariates, but because the ANOVA assumptions were violated, the results of those items are not discussed.

To determine investment attractiveness, participants were asked "How attractive do you find TWBC as a potential investment opportunity?” Participants rated this item using a fully labeled seven-point Likert scale with endpoints Very Bad $(-3)$ to Very Good $(+3)$. Analyses were again performed using non-parametric Mann-Whitney $U$ tests. Results show that participants in the positive performance condition (mean 1.711) rated TWBC as a significantly better investment opportunity than those in the negative performance condition (mean-0.857) $(p<0.001$, two-tailed). Further, within the negative performance condition, assurance significantly increases the attractiveness of the investment. Specifically, the no assurance cell (mean-1.412) is perceived to be a significantly less attractive investment opportunity when compared to the limited assurance cell (mean-0.273) 
$(p=0.007$, two-tailed) or the reasonable assurance cell (mean-0.571) $(\phi=0.049$, two-tailed). Significant differences were not identified within the positive performance condition. See Table IV for supporting analyses. These findings demonstrate a main effect of firm performance on investment attractiveness such that users perceive firms with positive environmental performance to be a better investment opportunity, and that the provision of assurance for firms with negative performance can enhance the attractiveness of the firm as an investment opportunity.

\subsection{Supplemental analyses}

In testing the no assurance condition, participants were asked to "please indicate the extent to which TWBC's greenhouse gas emission indicators were verified (i.e. assured)." Using a fully labeled seven-point Likert scale with endpoints No Verification (Assurance) (0) and High Verification (Assurance) (6), results show that 92.5 percent (62/67) of participants believed some level of assurance had been provided (i.e. more than zero) and 77.6 percent (52/67) of participants believed at least a moderate level of assurance had been provided. In the no assurance condition, there was no mention of assurance, which means users believed these disclosures were assured even when no explicit statement was offered. Therefore, it is not surprising that the study fails to find differences between reasonable assurance and no assurance in analyzing report believability, particularly in the positive performance condition. If non-expert users assume environmental reports are assured, then similar reactions should be expected when they (1) do not receive an assurance report or (2) receive a reasonable assurance report (that does not make it clear that a lower level of assurance exists). This is consistent with Low and Boo's (2012) finding that statements contrasting levels of assurance help less-informed users better understand the assurance being provided.

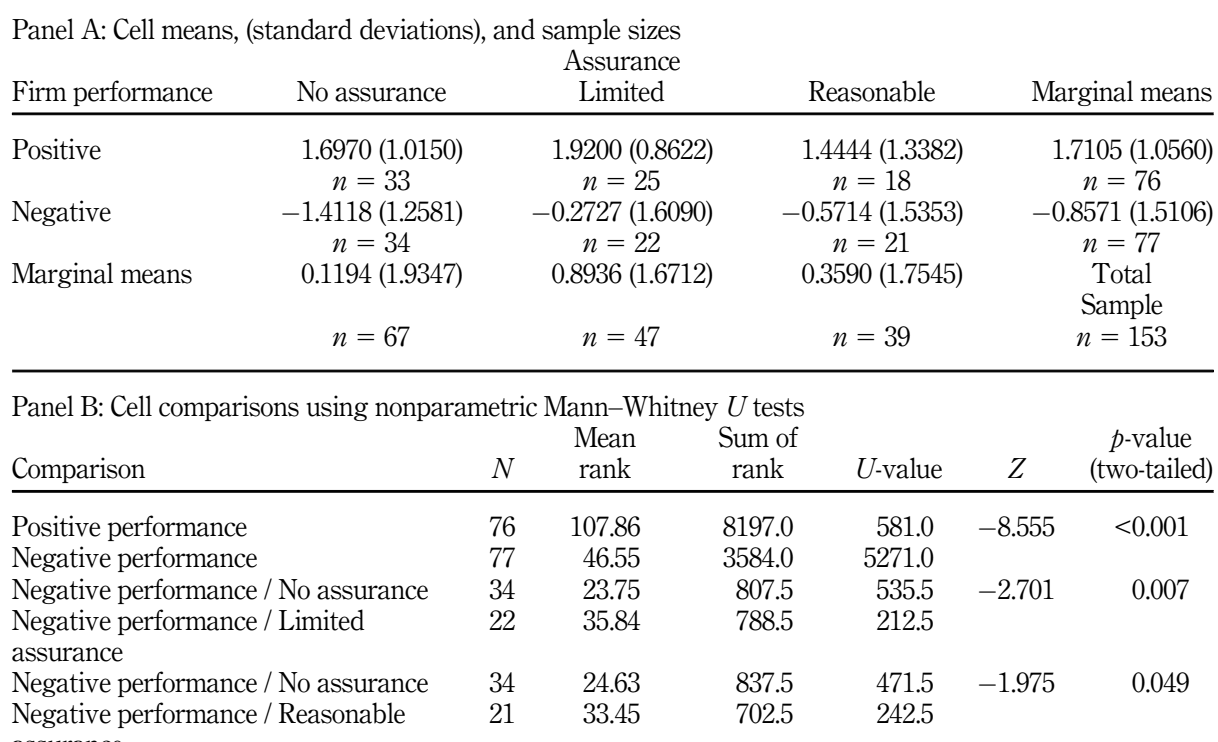
assurance

Note(s): This dependent variable asked participants to rate "How attractive do you find TWBC as a potential investment opportunity?” using a fully labeled seven-point Likert scale with endpoints Very Bad (-3) and Very Good $(+3)$

Table IV. Dependent variable: Potential investment opportunity 


\section{Discussion and conclusion}

This study examines whether non-expert environmental report users perceive a difference in the believability of management's environmental report based on a company's relative environmental performance or the level of assurance provided by an accounting firm under the recently clarified US attestation standards. It also investigated whether a firm's relative environmental performance interacted with the level of assurance to influence perceptions of environmental report believability.

Findings indicate that users perceive environmental reports to be believable, but there is no main effect for the provision/level of assurance obtained. Consistent with theory (e.g. Williams, 1996; Hutton et al., 2003; Mercer, 2004), there is a main effect for firm performance in which negative performance reports are perceived to be more believable than positive performance reports. Further analyses reveal this effect is driven by negative performance reports being perceived as significantly more believable when no assurance is present. The firm performance effect is eliminated when limited or reasonable assurance is provided. This study also identifies an interaction in which positive performance reports with limited assurance, but not reasonable assurance, are perceived to be more believable than reports with no assurance. No differences are identified in the believability of negative performance reports due to the provision or level of assurance.

Results of this study inform academic theory, practitioners, and standard setters. Theory on firm performance suggests that users find reports depicting negative firm performance to be more believable than reports depicting positive performance (e.g. Williams, 1996; Hutton et al., 2003; Mercer, 2004). This study reinforces firm performance theory when no assurance is present, but provides evidence that assurance on environmental reports can serve to eliminate differences in report believability that stem from firm performance. Within firm performance conditions, no differences in report believability were identified between the negative performance cells (i.e. when limited, reasonable, or no assurance was provided). This aligns with the notion that reports depicting negative performance are inherently believable, and assurance does not enhance this believability. However, within the positive performance condition, results indicate that environmental reports are perceived to be more believable with limited assurance rather than no assurance. This finding partially supports the notion that the influence of assurance is limited to positive performance conditions (Coram et al., 2009). One possible explanation for why users found the environmental report to be as believable with reasonable or no assurance is that users in the no assurance condition assumed the disclosures had been verified or assured (as previously discussed); as such, seeing a reasonable assurance report would only confirm this assumption. However, seeing a limited assurance report would also confirm this assumption, but also highlight that a higher level of assurance was not obtained by management, and it is plausible that this highlighted contrast in assurances is associated with the limited assurance benefit observed in the positive performance condition (Low and Boo, 2012). Indeed, this limited assurance benefit stands in contrast to Rivière-Giordano et al. (2018), who find that financial analysts are less likely to recommend firms with positive environmental performance that receive low rather than no assurance.

This study also contributes to the literature on the influence of different levels of assurance in a CSR context (e.g. Hasan et al., 2003; Hodge et al., 2009; Rivière-Giordano et al., 2018). Specifically, results indicate that users do not perceive a difference in report believability when offered limited or reasonable assurance in either a positive or negative performance setting. Further, while previous studies have focused on the impact of CSR information on firm valuation and investment decisions (e.g. Hasan et al., 2003; Dhaliwal et al., 2012; Elliott et al., 2014; Reimsbach et al., 2018; Rivière-Giordano et al., 2018), this study focuses on whether these disclosures are believable to the broader group of stakeholders who 
are not necessarily evaluating the information as part of a wealth-maximization decision. This is an important group to study as a company's environmental impact has implications for a broad range of stakeholders beyond those considering the firm as a financial investment (Moser and Martin, 2012). Results indicate that this user group finds environmental CSR reports to be generally believable, but their perceptions of believability can be impacted by firm performance and the provision of limited assurance in specific settings.

From a practitioner standpoint, this study demonstrates conditions in which users respond differently to positive and negative environmental performance. Specifically, negative performance reports are perceived to be more believable, but only when not assured. If a firm seeks to use its environmental report to speak to a broader group of stakeholders, this study suggests that limited assurance is an effective tool to manage impressions and enhance report believability when performance is positive. As such, findings suggest firms that invest in environmental activities and report positive results should consider obtaining the lower (and less costly) level of assurance to enhance the believability of their environmental report. From a standard-setter perspective, findings demonstrate the importance of clearly communicating to users when no assurance or verification is provided on environmental reports (the study finds that many users believed the non-assured reports had received assurance). As such, this study calls into question whether users would benefit from formal reporting requirements that have companies explicitly specify when no assurance is provided on environmental disclosures/reports.

This study is subject to several limitations. First, as the believability index did not conform to the assumptions of ANOVA, the analysis of potential covariates was limited. Second, the study could not show which element of the environmental disclosures participants responded to most strongly. For example, it could have been (1) the numerical distance between TWBC's performance and the industry average, (2) the displayed percentage differences, or (3) the narrative associated with TWBC's performance. Finally, this study focused on one aspect of environmental reporting, that being greenhouse gas emissions. Future research should consider responses to other aspects of environmental reporting, such as water usage or energy efficiency.

While environmental CSR reporting remains a largely voluntary activity in the US, it is important to further understand the users of this information and the attributes of reporting that they respond to differently. As this reporting becomes more structured, formalized, and prevalent, it will also remain critical to closely monitor the expectations and vulnerabilities of report users. We hope this study helps further the collective understanding of such users.

\section{Notes}

1. CSR reporting is "largely" voluntary in the US, with the exception of (1) required US Securities \& Exchange Commission disclosures, (2) the Dodd-Frank Act requirement to disclose conflict minerals, and (3) the mandate for federal agencies to report CSR performance under Presidential Executive Order 13,514 (KPMG, 2013). Examples of CSR disclosures required by the Securities \& Exchange Commission include those prescribed in release No. 33-9,106, Commission Guidance Regarding Disclosure Related to Climate Change, and release No. 34-67716, Conflict Minerals (Littan, 2014).

2. This is a change from the superseded U.S. standard, AT-101, Attest Engagements (AICPA, 2001), which refers to high and moderate assurances.

3. Hasan et al. (2003) use high and moderate assurances as defined in ISAE 100 . However, ISAE 100 was superseded by ISAE 3000 in 2000, and soon thereafter required the use of limited and reasonable assurances. Legacy ISAEs and U.S. Statements on Standards for Attestation Engagements (SSAEs) have both described assurance levels as high or moderate, yet the current standards refer to these assurances as limited and reasonable (IAASB, 2013; AICPA, 2016). In all cases, and as used 
throughout this study, reasonable and high assurances are used to describe levels of assurance that are stronger than limited or moderate.

4. CSR reporting firms might also fear a backlash from report users when specific disclosures are discontinued, much in the same way that firms fear investor reactions to discontinued earnings guidance (cf. Chen et al., 2011). By keeping the recurring CSR indicators and adding more over time, CSR reports will naturally grow and inevitably present more balanced reporting of positive and negative performance indicators. However, this assumes that firms will not be able to maintain purely positive performance across an ever growing and diversifying set of CSR disclosures.

5. IRB approval was obtained from the university where the authors were located at the time of the study for the use of human subjects for this experiment.

6. Participants closely resemble non-professional investors. Owens and Hawkins (2019) point out that "nonprofessional investor participants recruited from MTurk are reasonably good participants for nonprofessional investor research," and as such, may be used to answer a variety of research questions (p. 3). Hunt and Scheetz (2019) provide a list of other accounting studies that have also used MTurk to recruit non-professional investors, which includes Rennekamp (2012), Bonner (2014), Farkas and Murthy (2014), Triki et al. (2015), and Kelton and Murthy (2016). Finally, Farrell et al. (2016) find that MTurk participants can serve as valid proxies for non-experts in accounting research.

7. Selected G4 indicators are defined by the GRI as follows:

G4-EN15: Direct greenhouse gas emissions (Scope 1): "Emissions from operations that are owned or controlled by the organization" (GRI, 2013).

G4-EN16: Energy indirect greenhouse gas emissions (Scope 2): "Emissions that result from the generation of purchased or acquired electricity, heating, cooling, and steam consumed by the organization" (GRI, 2013).

G4-EN17: Other indirect greenhouse gas emissions (Scope 3): "Other indirect greenhouse gas emissions are all indirect emissions (not included in Scope 2) that occur outside of the organization, including both upstream and downstream emissions" (GRI, 2013).

G4-EN19: Reduction of greenhouse gas emissions: "A decrease in greenhouse gas emissions or an increase in removal or storage of greenhouse gas emissions from the atmosphere, relative to baseline emissions" (GRI, 2013).

8. Eutsler and Lang (2015) find that having all points labeled minimizes response bias, maximizes variance and power, and minimizes error. They also find that seven-point scales may maximize variance.

\section{References}

Adams, C. (2004), "The ethical, social and environmental reporting performance portrayal gap", Accounting, Auditing and Accountability Journal, Vol. 17 No. 5, pp. 731-757.

Al-Tuwaijri, S.A., Christensen, T.E. and Hughes Ii, K.E. (2004), "The relations among environmental disclosure, environmental performance, and economic performance: a simultaneous equations approach", Accounting, Organizations and Society, Vol. 29 Nos 5-6, pp. 447-471.

American Institute of Certified Public Accountants (AICPA) (2001), Attest Engagements - At Section 101, AICPA, New York, NY.

AICPA (2013a), Exposure Draft - Proposed Statement on Standards for Attestation Engagements; Attestation Standards: Clarification and Recodification (July 24, 2013), AICPA, New York, NY.

AICPA (2013b), Statement of Position 13-1: Attest Engagements on Greenhouse Gas Emissions Information, AICPA, New York, NY.

AICPA (2016), "Statements on standards for attestation engagements No. 18", available at: https:// www.aicpa.org/content/dam/aicpa/research/standards/auditattest/downloadabledocuments/ssaeno-18.pdf (accessed 5 November 2018).

AICPA (2017), Attestation Engagements on Sustainability Information Guide (Including Greenhouse Gas Emissions Information), AICPA, New York, NY. 
Ballou, B., Casey, R.J., Grenier, J.H. and Heitger, D.L. (2012), "Exploring the strategic integration of sustainability initiatives: opportunities for accounting research", Accounting Horizons, Vol. 26 No. 2, pp. 265-288.

Beyer, A., Cohen, D.A., Lys, T.Z. and Walther, B.R. (2010), "The financial reporting environment: review of the recent literature", Journal of Accounting and Economics, Vol. 50 No. 2, pp. 296-343.

Birkey, R., Michelon, G., Patten, D.M. and Sankara, J. (2016), "Does assurance on CSR reporting enhance environmental reputation? An examination in the US context", Accounting Forum, Vol. 40 No. 3, pp. 143-152.

Boiral, O. and Gendron, Y. (2011), "Sustainable development and certification practices: lessons learned and prospects", Business Strategy and the Environment, Vol. 20 No. 5, pp. 331-347.

Boiral, O. (2013), "Sustainability reports as simulacra? A counter-account of A and A+ GRI reports", Accounting, Auditing \& Accountability Journal, Vol. 26 No. 7, pp. 1036-1071.

Bonner, S.E. (2014), "Mental accounting and disaggregation based on the sign and relative magnitude of income items", The Accounting Review, Vol. 89 No. 6, pp. 2087-2114.

Casey, R.J. and Grenier, J.H. (2015), "Understanding and contributing to the enigma of corporate social responsibility (CSR) assurance in the United States", Auditing: A Journal of Practice and Theory, Vol. 34 No. 1, pp. 97-130.

Chen, S., Matsumoto, D. and Rajgopal, S. (2011), "Is silence golden? An empirical analysis of firms that stop giving quarterly earnings guidance", Journal of Accounting and Economics, Vol. 51 No. 1, pp. 134-150.

Cho, C.H. and Patten, D.M. (2007), "The role of environmental disclosures as tools of legitimacy: a research note", Accounting, Organizations and Society, Vol. 32 Nos 7-8, pp. 639-647.

Cho, C.H., Roberts, R.W. and Patten, D.M. (2010), "The language of US corporate environmental disclosure", Accounting, Organizations and Society, Vol. 35 No. 4, pp. 431-443.

Cho, C.H., Freedman, M. and Patten, D.M. (2012), "Corporate disclosure of environmental capital expenditures: a test of alternative theories", Accounting, Auditing and Accountability Journal, Vol. 25 No. 3, pp. 486-507.

Cho, C.H., Michelon, G., Patten, D.M. and Roberts, R.W. (2014), "CSR report assurance in the USA: an empirical investigation of determinants and effects", Sustainability Accounting, Management and Policy Journal, Vol. 5 No. 2, pp. 130-148.

Cho, C.H., Laine, M., Roberts, R.W. and Rodrigue, M. (2015a), "Organized hypocrite, organizational façades, and sustainability reporting”, Accounting, Organizations and Society, Vol. 40, pp. 78-94.

Cho, C.H., Michelon, G., Patten, D.M. and Roberts, R.W. (2015b), "CSR disclosure: the more things change... ?", Accounting, Auditing and Accountability Journal, Vol. 28 No. 1, pp. 14-35.

Cohen, E. (2014), "Balancing good news and bad news in sustainability reporting", available at: http:// www.triplepundit.com/2014/01/balancing-good-news-bad-news-sustainability-reporting/ (accessed 5 November 2018).

Cohen, J.R., Holder-Webb, L.L., Nath, L. and Wood, D. (2012), "Corporate reporting of nonfinancial leading indicators of economic performance and sustainability", Accounting Horizons, Vol. 26 No. 1 , pp. $65-90$.

Cohen, J.R. and Simnett, R. (2015), "CSR and assurance services: a research agenda", Auditing: A Journal of Practice and Theory, Vol. 34 No. 1, pp. 59-74.

Coram, P.J., Monroe, G.S. and Woodliff, D.R. (2009), "The value of assurance on voluntary nonfinancial disclosure: an experimental evaluation", Auditing: A Journal of Practice and Theory, Vol. 28 No. 1, pp. 137-151.

Corder, G.W. and Foreman, D.I. (2014), Nonparametric Statistics: A Step-by-step Approach, 2nd ed., John Wiley and Sons, Hoboken, NJ. 
Deegan, C. and Gordon, B. (1996), "A study of the environmental disclosure practices of Australian corporations", Accounting and Business Research, Vol. 26 No. 3, pp. 187-199.

Deegan, C. and Rankin, M. (1996), "Do Australian companies report environmental news objectively? An analysis of environmental disclosures by firms prosecuted successfully by the Environmental Protection Authority”, Accounting, Auditing \& Accountability Journal, Vol. 9 No. 2, pp. 50-67.

Dhaliwal, D., Radhakrishnan, S., Tsang, A. and Yang, Y.G. (2012), "Nonfinancial disclosure and analyst forecast accuracy: international evidence on corporate social responsibility disclosure", The Accounting Review, Vol. 87 No. 3, pp. 723-759.

Eagly, A.H., Wood, W. and Chaiken, S. (1978), "Causal inferences about communicators and their effect on opinion change", Journal of Personality and Social Psychology, Vol. 36 No. 4, pp. 424.

Elliott, W.B., Jackson, K.E., Peecher, M.E. and White, B.J. (2014), "The unintended effect of corporate social responsibility performance on investors' estimates of fundamental value", The Accounting Review, Vol. 89 No. 1, pp. 275-302.

Eutsler, J. and Lang, B. (2015), "Rating scales in accounting research: the impact of scale points and labels", Behavioral Research in Accounting, Vol. 27 No. 2, pp. 35-51.

Fargher, N. and Gramling, A.A. (2003), "Research note: the influence of attestation on users' perceptions of assertion credibility in the asset management industry", International Journal of Auditing, Vol. 7 No. 1, pp. 87-100.

Farkas, M. and Murthy, U.S. (2014), "Nonprofessional investors' perceptions of the incremental value of continuous auditing and continuous controls monitoring: an experimental investigation", International Journal of Accounting Information Systems, Vol. 15, pp. 102-121.

Farrell, A.M., Grenier, J.H. and Leiby, J. (2016), "Scoundrels or stars? Theory and evidence on the quality of workers in online labor markets", The Accounting Review, Vol. 92 No. 1, pp. 93-114.

Flanagin, A.J. and Metzger, M.J. (2000), "Perceptions of Internet information credibility", Journalism and Mass Communication Quarterly, Vol. 77 No. 3, pp. 515-540.

Foster, M. (2012), "PwC acquires environmental consulting group virdis", available at: http://www. big4.com/pricewaterhousecoopers/pwc-acquires-environmental-consulting-group-viridis/ (accessed 5 November 2018).

Gay, G., Schelluch, P. and Baines, A. (1998), "Perceptions of messages conveyed by review and audit reports", Accounting, Auditing and Accountability Journal, Vol. 11 No. 4, pp. 472-494.

Global Reporting Initiative (GRI) (2013), "G4 Sustainability reporting guidelines”, available at: https:// www.globalreporting.org/reporting/g4/Pages/default.aspx (accessed 15 December 2015).

GRI (2014a), “About sustainability reporting”, available at: https://www.globalreporting.org (accessed 15 December 2015).

GRI (2014b), "Update on the US: trends in external assurance of sustainability reports", available at: https://www.globalreporting.org (accessed 15 December 2015).

GRI (2014c), "Emissions | indicators", available at: https://www.globalreporting.org (accessed 15 December 2015).

Green, W. and Li, Q. (2011), "Evidence of an expectation gap for greenhouse gas emissions assurance", Accounting, Auditing and Accountability Journal, Vol. 25 No. 1, pp. 146-173.

Green, W. and Zhou, S. (2013), "An International examination of assurance practices on carbon emissions disclosures", Australian Accounting Review, Vol. 23 No. 1, pp. 54-66.

Gunther, M. (2010), "Deloitte boosts green cred with purchase of ClearCarbon, domani”, available at: http://www.greenbiz.com/blog/2010/12/15/deloitte-boosts-green-cred-purchase-clearcarbon-domani (accessed 5 November 2018).

Hasan, M., Roebuck, P.J. and Simnett, R. (2003), "An Investigation of alternative report formats for communicating moderate levels of assurances", Auditing: A Journal of Practice \& Theory, Vol. 22 No. 2, pp. 171-187. 
Hodge, K., Subramaniam, N. and Stewart, J. (2009), "Assurance of sustainability reports: impact on report users' confidence and perceptions of information credibility", Australian Accounting Review, Vol. 19 No. 3, pp. 178-194.

Holder-Webb, L., Cohen, J.R., Nath, L. and Wood, D. (2009), "The supply of corporate social responsibility disclosures among US firms", Journal of Business Ethics, Vol. 84 No. 4, pp. 497-527.

Hughes, S.B., Anderson, A. and Golden, S. (2001), "Corporate environmental disclosures: are they useful in determining environmental performance?", Journal of Accounting and Public Policy, Vol. 20, pp. 217-240.

Hunt, N.C. and Scheetz, A.M. (2019), "Using MTurk to distribute a survey or experiment: methodological considerations", Journal of Information Systems, Vol. 33 No. 1, pp. 43-65.

Hutton, A.P., Miller, G.S. and Skinner, D.J. (2003), "The role of supplementary statements with management earnings forecasts", Journal of Accounting Research, Vol. 41 No. 5, pp. 867-890.

International Auditing and Assurance Standards Board (IAASB) (2013), "International Standards on Assurance Engagements 3000 (Revised): assurance engagements other than audits or reviews of historical financial information", available at: https:/www.ifac.org/sites/default/files/publications/ files/ISAE $\% 203000 \% 20$ Revised $\% 20$ - $\% 20$ for $\% 20$ IAASB.pdf (accessed 5 November 2018).

Junior, R.M., Best, P.J. and Cotter, J. (2014), "Sustainability reporting and assurance: a historical analysis on a world-wide phenomenon", Journal of Business Ethics, Vol. 120 No. 1, pp. 1-11.

Kelton, A.S. and Murthy, U.S. (2016), "The effects of information disaggregation and financial statement interactivity on judgments and decisions of nonprofessional investors", Journal of Information Systems, Vol. 30 No. 3, pp. 99-118.

Keppel, G. (1991), Design and Analysis: A Researcher's Handbook, Prentice-Hall, Englewood Cliffs, NJ.

Kinney, W. (2000), Information Quality Assurance and Internal Control, Irwin/McGraw-Hill, Burr Ridge, IL.

KPMG and SustainAbility (2008), "Count me in: the readers' take on sustainability reporting", available at: https://home.kpmg.com/gr/en/home/insights.html (accessed 15 December 2015).

KPMG (2013), “The KPMG survey of corporate responsibility reporting 2013”, available at: www. kpmg.com (accessed 15 December 2015).

KPMG (2017), "The KPMG survey of corporate responsibility reporting 2017", available at: www. kpmg.com (accessed 15 December 2015).

Lackmann, J., Ernstberger, J. and Stich, M. (2012). "Market reactions to increased reliability of sustainability information", Journal of Business Ethics, Vol. 107 No. 2, pp. 111-128.

Lipe, M.G. and Salterio, S.E. (2000), "The balanced scorecard: judgmental effects of common and unique performance measures", The Accounting Review, Vol. 75 No. 3, pp. 283-298.

Littan, S. (2014), "Executive perspective: corporate sustainability reporting, where the world is today", available at: http://sustainability.thomsonreuters.com/2014/12/13/executive-perspective-corporatesustainability-reporting-world-today/ (accessed 5 November 2018).

Low, K.Y. and Boo, E.F. (2012), "Do contrasting statements improve users' understanding of different assurance levels conveyed in assurance reports?", International Journal of Auditing, Vol. 16 No. 1, pp. 19-34.

Mahoney, L.S., Thorne, L., Cecil, L. and LaGore, W. (2013), “A research note on standalone corporate social responsibility reports: signaling or greenwashing?”, Critical Perspectives on Accounting, Vol. 24 Nos 4-5, pp. 350-359.

Martin, P.R. and Moser, D.V. (2016), “Managers' green investment disclosures and investors' reaction”, Journal of Accounting and Economics, Vol. 61 No. 1, pp. 239-254.

McNichols, M. (1989), "Evidence of informational asymmetries from management earnings forecasts and stock returns", The Accounting Review, Vol. 64 No. 1, pp. 1-27. 
Mercer, M. (2004), "How do investors assess the credibility of management disclosures?", Accounting Horizons, Vol. 18 No. 3, pp. 185-196.

Michelon, G., Pilonato, S. and Ricceri, F. (2015), "CSR reporting practices and the quality of disclosure: an empirical analysis", Critical Perspectives on Accounting, Vol. 33, pp. 59-78.

Moroney, R., Windsor, C. and Aw, Y.T. (2012), "Evidence of assurance enhancing the quality of voluntary environmental disclosures: an empirical analysis", Accounting and Finance, Vol. 52 No. 3, pp. 903-939.

Moser, D.V. and Martin, P.R. (2012), "A broader perspective on corporate social responsibility research in accounting", The Accounting Review, Vol. 87 No. 3, pp. 797-806.

Nugent, M. and Simnett, R. (2007), "Developing an assurance standard for carbon emissions disclosures", Australian Accounting Review, Vol. 17 No. 42, pp. 37-47.

O'Donovan, G. (1999), "Managing legitimacy through increased corporate environmental reporting: an exploratory study”, Interdisciplinary Environmental Review, Vol. 1 No. 1, pp. 63-99.

O'Dwyer, B. and Owen, D.L. (2005), "Assurance statement practice in environmental, social and sustainability reporting: a critical evaluation”, The British Accounting Review, Vol. 37 No. 2, pp. 205-229.

Owens, J. and Hawkins, E.M. (2019), "Using online labor market participants for nonprofessional investor research: a comparison of MTurk and Qualtrics samples", Journal of Information Systems, Vol. 33 No. 1, pp. 113-128.

Ozlanski, M.E. (2013), Effects of Principles vs. Rules Based Accounting Standards and Expanded Auditor Reporting on Investors' Perceptions of Management Reporting Credibility, $\mathrm{PhD}$ Virginia Polytechnic Institute and State University, Blasksburg, Virginia.

Perego, P. and Kolk, A. (2012), "Multinationals' accountability on sustainability: the evolution of thirdparty assurance of sustainability reports", Journal of Business Ethics, Vol. 110 No. 2, pp. 173-190.

Peters, G.F. and Romi, A.M. (2014), "The association between sustainability governance characteristics and the assurance of corporate sustainability reports", Auditing: A Journal of Practice and Theory, Vol. 34 No. 1, pp. 163-198.

Pflugrath, G., Roebuck, P. and Simnett, R. (2011), "Impact of assurance and assurer's professional affiliation on financial analysts' assessment of credibility of corporate social responsibility information", Auditing: A Journal of Practice and Theory, Vol. 30 No. 3, pp. 239-254.

Reimsbach, D., Hahn, R. and Gürtürk, A. (2018), "Integrated reporting and assurance of sustainability information: an experimental study on professional investors' information processing", European Accounting Review, Vol. 27 No. 3, pp. 559-581.

Rennekamp, K. (2012), "Processing fluency and investors' reactions to disclosure readability", Journal of Accounting Research, Vol. 50 No. 5, pp. 1319-1354.

Rivière-Giordano, G., Giordano-Spring, S. and Cho, C.H. (2018), "Does the level of assurance statement on environmental disclosure affect investor assessment?: an experimental study", Sustainability Accounting, Management and Policy Journal, Vol. 9 No. 3, pp. 336-360.

Schelluch, P. and Gay, G. (2006), "Assurance provided by auditors' reports on prospective financial information: implications for the expectation gap”, Accounting and Finance, Vol. 46 No. 4, pp. 653-676.

Simnett, R., Vanstraelen, A. and Chua, W.F. (2009), "Assurance on sustainability reports: an international comparison”, The Accounting Review, Vol. 84 No. 3, pp. 937-967.

Slovic, P. and MacPhillamy, D. (1974), "Dimensional commensurability and cue utilization in comparative judgment”, Organizational Behavior and Human Performance, Vol. 11 No. 2, pp. 172-194.

Talbot, D. and Boiral, O. (2018), "GHG reporting and impression management: an assessment of sustainability reports from the energy sector",Journal of Business Ethics, Vol.147 No. 2, pp. 367-383.

Triki, A., Arnold, V. and Sutton, S.G. (2015), "Too good to be true! the bifurcated effect of strong tone in management disclosures in investors' decisions", Advances in Accounting Behavioral Research, Vol. 18, pp. 1-31. 
Verrecchia, R.E. (1983), "Discretionary disclosure", Journal of Accounting and Economics, Vol. 5, pp. 179-194.

Williams, P.A. (1996), "The relation between a prior earnings forecast by management and analyst response to a current management forecast", The Accounting Review, Vol. 71 No. 1, pp. 103-115.

Wong, R. and Millington, A. (2014), "Corporate social disclosures: a user perspective on assurance", Accounting, Auditing and Accountability Journal, Vol. 27 No. 5, pp. 863-887.

\section{Appendix: Excerpts of experimental materials}

\section{A. Management's presentation and description of greenhouse gas emission performance-Positive performance condition}

Below is page 12 from the TWBCEnvironmental Sustainability Report. This page was written by TWBC management.

\section{Emissions}

This section describes the Tasty Water Beverage Company's (TWBC) greenhouse gas emissions using reporting indicators defined by the Global Reporting Initiative (GRI). The GRI is an organization that provides a standardized sustainability reporting framework to be used by companies around the world in reporting the results of sustainability activities.

The following table summarizes our results for select GRI indicators and includes the overall average performance of the Food and Beverage Industry along with a factor showing how our performance differed from the industry average for each indicator. As shown, our results for 2014 were better than the industry average for all indicators (see Table AI).

Direct greenhouse gas emissions are reported under the GRI indicator G4-EN15, which includes "emissions from operations that are owned or controlled by" TWBC. During 2014, we directly emitted 41.0 metric tons (in thousands) of $\mathrm{CO}_{2}$ (carbon dioxide) and $\mathrm{CO}_{2}$ equivalents into the environment. The primary sources for these emissions included our bottling plants, processing plants, and distribution trucks.

Energy indirect greenhouse gas emissions are reported under the GRI indicator G4-EN16, which includes "emissions that result from the generation of purchased or acquired electricity, heating, cooling, and steam consumed by" TWBC. During 2014, we emitted 94.5 metric tons (in thousands) of energy indirect $\mathrm{CO}_{2}$ and $\mathrm{CO}_{2}$ equivalents into the environment. The primary sources for these emissions included our heating, cooling, and powering of bottling and processing plants.

Other indirect greenhouse gas emissions are reported under the GRI indicator G4-EN17, which includes indirect emissions (not included in "energy indirect") that "occur outside of the organization, including both upstream and downstream emissions." During 2014, we emitted 62.9 metric tons (in thousands) of other indirect $\mathrm{CO}_{2}$ and $\mathrm{CO}_{2}$ equivalents into the environment. The primary sources for

\begin{tabular}{llccc}
\hline $\begin{array}{l}\text { GRI } \\
\text { indicator }\end{array}$ & Description & $\begin{array}{c}\text { TWBC } \\
\text { Results for } \\
2014\end{array}$ & $\begin{array}{c}\text { Food and Beverage } \\
\text { Industry average for } \\
2014\end{array}$ & $\begin{array}{c}\text { TWBC \% diff. from } \\
\text { industry average }\end{array}$ \\
\hline G4-EN15 & $\begin{array}{l}\text { Direct greenhouse gas } \\
\text { emissions }\end{array}$ & 41.0 & 102.9 & $-60.2 \%$ \\
G4-EN16 & $\begin{array}{l}\text { Energy indirect } \\
\text { greenhouse gas } \\
\text { emissions }\end{array}$ & 94.5 & 205.5 & $-54.0 \%$ \\
G4-EN17 & $\begin{array}{l}\text { Other indirect } \\
\text { greenhouse gas } \\
\text { emissions }\end{array}$ & 62.9 & 187.9 & $-66.5 \%$ \\
G4-EN19 & $\begin{array}{l}\text { Reduction of greenhouse } \\
\text { gas emissions }\end{array}$ & $62.4 \%$ & $1.3 \%$ & $+61.1 \%$ \\
Note(s): $C O_{2}^{\text {(and equivalent) emissions in thousands of metric tons }}$ & \\
\hline
\end{tabular}

Table AI. 
these emissions included our bottle producers, raw material (ingredients) providers, and from coolers at retail stores displaying our products.

Reductions of greenhouse gas emissions are reported under the GRI indicator G4-EN19. This year, we experienced a 62.4 percent reduction in total greenhouse gas emissions across our entire company (including direct, energy indirect, and other indirect emissions), as measured using baseline emissions established on December 31, 2013.

\section{B. Management's presentation and description of greenhouse gas emission performance-Negative performance condition}

Below is page 12 from the TWBCEnvironmental Sustainability Report. This page was written by TWBC management.

\section{Emissions}

This section describes the Tasty Water Beverage Company's (TWBC) greenhouse gas emissions using reporting indicators defined by the Global Reporting Initiative (GRI). The GRI is an organization that provides a standardized sustainability reporting framework to be used by companies around the world in reporting the results of sustainability activities.

The following table summarizes our results for select GRI indicators and includes the overall average performance of the Food and Beverage Industry along with a factor showing how our performance differed from the industry average for each indicator. As shown, our results for 2014 were worse than the industry average for all indicators (see Table AII).

Direct greenhouse gas emissions are reported under the GRI indicator G4-EN15, which includes "emissions from operations that are owned or controlled by" TWBC. During 2014, we directly emitted 164.8 metric tons (in thousands) of $\mathrm{CO}_{2}$ (carbon dioxide) and $\mathrm{CO}_{2}$ equivalents into the environment. The primary sources for these emissions included our bottling plants, processing plants, and distribution trucks.

Energy indirect greenhouse gas emissions are reported under the GRI indicator G4-EN16, which includes "emissions that result from the generation of purchased or acquired electricity, heating, cooling, and steam consumed by" TWBC. During 2014, we emitted 316.5 metric tons (in thousands) of energy indirect $\mathrm{CO}_{2}$ and $\mathrm{CO}_{2}$ equivalents into the environment. The primary sources for these emissions included our heating, cooling, and powering of bottling and processing plants.

Other indirect greenhouse gas emissions are reported under the GRI indicator G4-EN17, which includes indirect emissions (not included in "energy indirect") that "occur outside of the organization, including both upstream and downstream emissions.” During 2014, we emitted 312.9 metric tons (in thousands) of other indirect $\mathrm{CO}_{2}$ and $\mathrm{CO}_{2}$ equivalents into the environment. The primary sources for these emissions included our bottle producers, raw material (ingredients) providers, and from coolers at retail stores displaying our products.

Reductions (increases) of greenhouse gas emissions are reported under the GRI indicator G4-EN19. This year we experienced a 59.8 percent increase in total greenhouse gas emissions across our entire company (including direct, energy indirect, and other indirect emissions), as measured using baseline emissions established on December 31, 2013.

\begin{tabular}{|c|c|c|c|c|}
\hline $\begin{array}{l}\text { GRI } \\
\text { indicator }\end{array}$ & Description & $\begin{array}{l}\text { TWBC } \\
\text { results for } \\
2014\end{array}$ & $\begin{array}{c}\text { Food and Beverage } \\
\text { Industry average for } \\
2014\end{array}$ & $\begin{array}{l}\text { TWBC } \% \text { diff. from } \\
\text { industry average }\end{array}$ \\
\hline G4-EN15 & $\begin{array}{l}\text { Direct greenhouse gas } \\
\text { emissions }\end{array}$ & 164.8 & 102.9 & $+60.2 \%$ \\
\hline G4-EN16 & $\begin{array}{l}\text { Energy indirect } \\
\text { greenhouse gas emissions }\end{array}$ & 316.5 & 205.5 & $+54.0 \%$ \\
\hline G4-EN17 & $\begin{array}{l}\text { Other indirect greenhouse } \\
\text { gas emissions }\end{array}$ & 312.9 & 187.9 & $+66.5 \%$ \\
\hline G4-EN19 & $\begin{array}{l}\text { Reduction (increase) of } \\
\text { greenhouse gas emissions }\end{array}$ & $(59.8 \%)$ & $1.3 \%$ & $-61.1 \%$ \\
\hline
\end{tabular}




\section{Independent Accountant's Report}

Panel A displays the full Independent Accountant's Report provided in the positive performance, reasonable assurance, condition. Panels B, C, and D describe/display how this report varies from Panel A for the remaining conditions that received assurance.

\section{Panel A-Positive performance, reasonable assurance}

Independent Accountant's Report. Tasty Water Beverage Company Board of Directors and Management:

We have examined the following selected environmental data (the "selected indicators") included on page 12 of The Tasty Water Beverage Company's 2014 Environmental Sustainability Report (the "Report") for the year ended December 31, 2014. Tasty Water Beverage Company's management is responsible for the selected indicators, based on the reporting criteria referenced in Table AIII below. Our responsibility is to express an opinion on the indicators included in Table AIII based on our examination.

Our examination was conducted in accordance with attestation standards established by the American Institute of Certified Public Accountants. Those standards require that we plan and perform the examination to obtain reasonable assurance about whether the indicators in Table AIII are presented in accordance with the referenced criteria, in all material respects. An examination involves performing procedures to obtain evidence about the selected indicators. The nature, timing, and extent of the procedures selected depend on our judgment, including an assessment of the risks of material misstatement of the selected indicators, whether due to fraud or error. We believe that the evidence we obtained is sufficient and appropriate to provide a reasonable basis for our opinion.

Environmental and energy use data are subject to measurement uncertainties resulting from limitations inherent in the nature and the methods used for determining such data. The selection of different but acceptable measurement techniques can result in materially different measurements. The precision of different measurement techniques may also vary.

In our opinion, the selected indicators presented in Table AIII for the Tasty Water Beverage Company for the year ended December 31, 2014 are presented in accordance with the referenced reporting criteria, in all material respects.

(Large International Accounting Firm)

New York, New York

February 18, 2015

Panel B-Positive performance, Limited assurance

The title of this report is modified as prescribed by the AICPA and appears as the "Independent Accountant's Review Report" to reflect the limited (rather than reasonable) level of assurance provided

\begin{tabular}{|c|c|c|c|}
\hline Description & Measurement & $\begin{array}{c}2014 \\
\text { results }\end{array}$ & Reporting criteria \\
\hline $\begin{array}{l}\text { Direct greenhouse gas } \\
\text { emissions (scope 1) }\end{array}$ & $\begin{array}{l}\text { Greenhouse gas emissions } \\
\text { measured in metric tons of } \\
\mathrm{CO}_{2} \text { equivalents }\end{array}$ & 41.0 & $\begin{array}{l}\text { World Resources Institute (WRI)/World } \\
\text { Business Council for Sustainable } \\
\text { Development (WBCSD) Greenhouse } \\
\text { Gas Protocol_-Revised Edition }\end{array}$ \\
\hline $\begin{array}{l}\text { Energy indirect } \\
\text { greenhouse gas } \\
\text { emissions (scope 2) }\end{array}$ & $\begin{array}{l}\text { Greenhouse gas emissions } \\
\text { measured in metric tons of } \\
\mathrm{CO}_{2} \text { equivalents }\end{array}$ & 94.5 & $\begin{array}{l}\text { World Resources Institute (WRI)/World } \\
\text { Business Council for Sustainable } \\
\text { Development (WBCSD) Greenhouse } \\
\text { Gas Protocol_Revised Edition }\end{array}$ \\
\hline $\begin{array}{l}\text { Other indirect } \\
\text { greenhouse gas } \\
\text { emissions (scope 3) }\end{array}$ & $\begin{array}{l}\text { Greenhouse gas emissions } \\
\text { measured in metric tons of } \\
\mathrm{CO}_{2} \text { equivalents }\end{array}$ & 62.9 & $\begin{array}{l}\text { World Resources Institute (WRI)/World } \\
\text { Business Council for Sustainable } \\
\text { Development (WBCSD) Greenhouse } \\
\text { Gas Protocol_Revised Edition }\end{array}$ \\
\hline $\begin{array}{l}\text { Reduction of } \\
\text { greenhouse gas } \\
\text { emissions }\end{array}$ & $\begin{array}{l}\text { Percentage decrease in total } \\
\text { greenhouse gas emissions } \\
\text { from prior year }\end{array}$ & $62.4 \%$ & $\begin{array}{l}\text { World Resources Institute (WRI)/World } \\
\text { Business Council for Sustainable } \\
\text { Development (WBCSD) Greenhouse } \\
\text { Gas Protocol_Revised Edition }\end{array}$ \\
\hline
\end{tabular}

Table AIII. 


\begin{tabular}{|c|c|c|c|}
\hline Description & Measurement & $\begin{array}{c}2014 \\
\text { results }\end{array}$ & Reporting criteria \\
\hline $\begin{array}{l}\text { Direct greenhouse gas } \\
\text { emissions (scope 1) }\end{array}$ & $\begin{array}{l}\text { Greenhouse gas emissions } \\
\text { measured in metric tons of } \\
\mathrm{CO}_{2} \text { equivalents }\end{array}$ & 164.8 & $\begin{array}{l}\text { World Resources Institute (WRI)/World } \\
\text { Business Council for Sustainable } \\
\text { Development (WBCSD) Greenhouse } \\
\text { Gas Protocol-Revised Edition }\end{array}$ \\
\hline $\begin{array}{l}\text { Energy indirect } \\
\text { greenhouse gas } \\
\text { emissions (scope 2) }\end{array}$ & $\begin{array}{l}\text { Greenhouse gas emissions } \\
\text { measured in metric tons of } \\
\mathrm{CO}_{2} \text { equivalents }\end{array}$ & 316.5 & $\begin{array}{l}\text { World Resources Institute (WRI)/World } \\
\text { Business Council for Sustainable } \\
\text { Development (WBCSD) Greenhouse } \\
\text { Gas Protocol-Revised Edition }\end{array}$ \\
\hline $\begin{array}{l}\text { Other indirect } \\
\text { greenhouse gas } \\
\text { emissions (scope 3) }\end{array}$ & $\begin{array}{l}\text { Greenhouse gas emissions } \\
\text { measured in metric tons of } \\
\mathrm{CO}_{2} \text { equivalents }\end{array}$ & 312.9 & $\begin{array}{l}\text { World Resources Institute(WRI)/World } \\
\text { Business Council for Sustainable } \\
\text { Development (WBCSD) Greenhouse } \\
\text { Gas Protocol-Revised Edition }\end{array}$ \\
\hline $\begin{array}{l}\text { Reduction (increase) of } \\
\text { greenhouse gas } \\
\text { emissions }\end{array}$ & $\begin{array}{l}\text { Percentage decrease in total } \\
\text { greenhouse gas emissions } \\
\text { from prior year }\end{array}$ & $(59.8 \%)$ & $\begin{array}{l}\text { World Resources Institute(WRI)/World } \\
\text { Business Council for Sustainable } \\
\text { Development (WBCSD) Greenhouse } \\
\text { Gas Protocol-Revised Edition }\end{array}$ \\
\hline
\end{tabular}

by the accounting firm. Further, throughout the report where Panel A refers to examinations/opinions, Panel B refers to reviews/conclusions. Finally, the scope and opinion/conclusion paragraphs appear as follows:

Scope paragraph. Our review was conducted in accordance with attestation standards established by the American Institute of Certified Public Accountants. Those standards require that we plan and perform the review to obtain limited assurance about whether any material modifications should be made to the selected indicators in order for each to be presented in accordance with the criteria identified above. A review is substantially less in scope than an examination, the objective of which is to obtain reasonable assurance about whether the selected indicators are presented in accordance with the criteria, in all material respects, in order to express an opinion. Accordingly, we do not express such an opinion. We believe that our review provides a reasonable basis for our conclusion.

Opinion/conclusion paragraph. Based on our review, we are not aware of any material modifications that should be made to the selected indicators in Table AIV for the Tasty Water Beverage Company for the year ended December 31, 2014, in order for each indicator to be in accordance with the referenced reporting criteria.

Panel C-Negative performance, reasonable assurance

In contrast to Panel A, Panel C presents negative performance information in the "2014 Results" section of Table AIV as follows:

Panel D-Negative performance, limited assurance

This report is modified to present a review with limited assurance, as described in Panel B. Further, this report reflects negative performance and therefore displays Table AIII as shown in Panel C.

\section{Corresponding author}

Mark D. Sheldon can be contacted at: msheldon@jcu.edu 